\title{
FINANCIAL REPORTING OPACITY AND INFORMED TRADING BY INTERNAITONAL INSTITUTIONAL INVESTORS
}

\author{
Mark G. Maffett
}

A dissertation submitted to the faculty of the University of North Carolina at Chapel Hill in partial fulfillment of the requirements for the degree of Doctor of Philosophy in the KenanFlagler School of Business.

Chapel Hill

2012

Approved by:

Mark H. Lang

Jeffery Abarbanell

Robert M. Bushman

Wayne R. Landsman

Christian T. Lundblad 


\begin{abstract}
MARK G. MAFFETT: Financial Reporting Opacity and Informed Trading by International Institutional Investors

(Under the direction of Mark H. Lang)
\end{abstract}

Using cross-country data on trading by international mutual funds, I find that firms with more opaque information environments, as captured by firm- and country-level measures of the availability of financial reporting information, experience more privately-informed trading by institutional investors. The association between firm-level opacity and informed trading is most pronounced where country-level disclosure infrastructures are less developed and for those investors for whom the incentives and opportunities to acquire private information are greatest. A difference-in-differences analysis of returns earned by institutions across opaque and transparent firms suggests these results are economically significant. 
To Jackie and Maya 


\section{ACKNOWLEDGEMENTS}

This paper has benefited tremendously from the guidance and support of my dissertation

committee members: Mark Lang (advisor), Jeff Abarbanell, Robert Bushman, Wayne Landsman and Christian Lundblad. I am also grateful for helpful comments from S.P. Kothari (editor), Brian Bushee (JAE discussant), an anonymous reviewer, Dan Amiram, Mary Barth, John Gallemore, Joseph Gerakos, John Hand, Justin Hopkins, Susan Hughes, Andrew Karolyi, Christian Leuz, Tom Lys, Ed Maydew, Katie McDermott, Derrald Stice, Robert Verrecchia and seminar participants at the 2011 Journal of Accounting \& Economics Conference, the 2011 American Accounting Association Annual Meeting, the University of North Carolina at Chapel Hill and Wake Forest University. I gratefully acknowledge funding from the Deloitte Foundation, the State Farm Companies Foundation and the AAA/Grant Thornton Doctoral Dissertation Award. 


\section{TABLE OF CONTENTS}

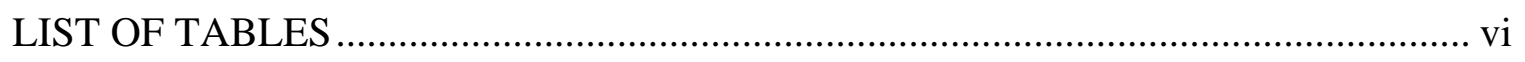

\section{FINANCIAL REPORTING OPACITY AND INFORMED TRADING BY}

INTERNATIONAL INSTITUTIONAL INVESTORS.........................................................

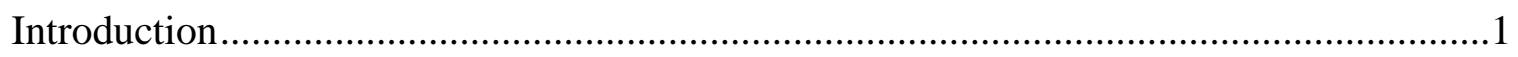

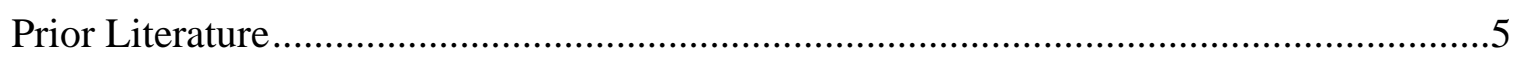

Empirical Predictions .........................................................................................

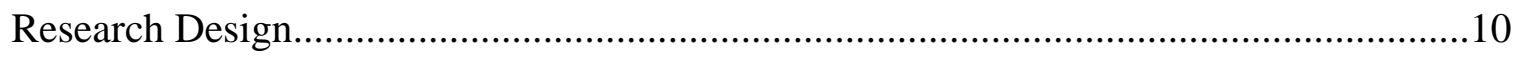

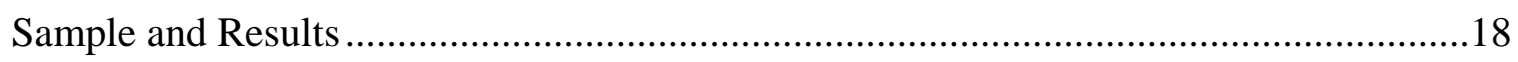

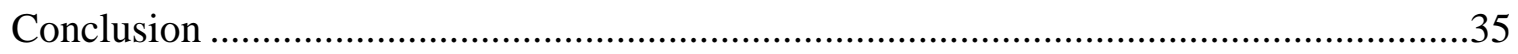

Appendix A. Timeline for Variable Measurement ..............................................................49

Appendix B. Variable Definitions ...........................................................................50

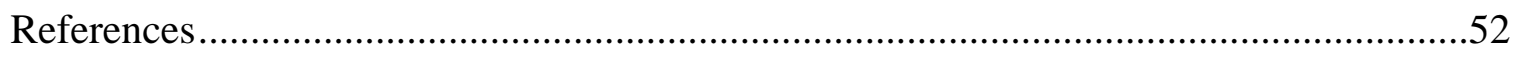




\section{LIST OF TABLES}

Table

1. Breakdown of the Sample By Country .........................................................38

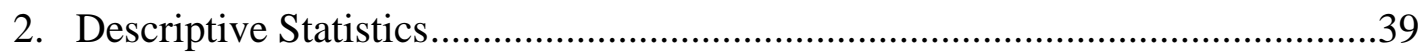

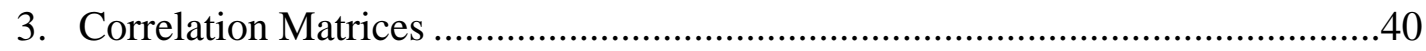

4. Informed Trading by Institutions and Firm-Level Opacity ..............................41

5. Informed Trading by Institutions and Country-Level Opacity .........................42

6. Additional Analyses and Robustness Tests ................................................43

7. Firm- and Country-Level Opacity Interactions...........................................44

8. Informed Trading and Opacity by Institutional Type ....................................45

9. Difference-in-Differences Returns Tests ....................................................48 


\section{Introduction}

A substantial body of prior research explores whether institutional investors trade based on superior information. While many studies show that, on average, institutions underperform their appropriate benchmarks [e.g., Carhart (1997)], others suggest that certain subsets of institutional investors can consistently forecast future returns [e.g., Yan and Zhang (2009)]. However, we know less about how those institutions that can earn excess returns actually do and, in particular, whether the transparency of the target firm's information environment is an important determinant of the extent and profitability of their informed trades. In this paper, I address this question directly and explore how institutional investors create private informational advantages by examining the relation between informed institutional trading, as captured by a positive association between changes in holdings and future returns, and the opacity of firms’ public financial reporting. ${ }^{1}$ To provide a deeper understanding of this relation, I also investigate where and for whom an opaque financial reporting environment provides the greatest benefit for private information-based trading. ${ }^{2}$

\footnotetext{
${ }^{1}$ Throughout the paper, I assume a positive association between changes in institutional holdings and future returns, controlling for risk and prior performance, is indicative of informed trading and frequently refer to it as such.

${ }^{2}$ Throughout the paper, I follow Bushman et al. (2004) and define opacity as the unavailability of firm-specific information to those outside publicly traded firms. For parsimony, I frequently refer to this construct as 'opacity'.
} 
At a conceptual level, there are compelling reasons to believe the extent of institutional investors' informed trading could be increasing in the opacity of firms' financial reporting. Specifically, although prior literature suggests that financial reporting transparency can have significant benefits for the average investor [e.g., Lang and Maffett (2011a)], as noted by Verrecchia (1982) and Diamond (1985), less public disclosure can also motivate more private information gathering. A greater extent of private information acquisition increases information asymmetry and creates the possibility for better-informed investors to gain at the expense of others by trading on their information advantages. This suggests that certain subsets of investors may actually benefit from more opaque financial reporting. Moreover, although private information acquisition is costly and beyond the means of many investors, sophisticated investors, such as institutions, likely have significant capital and expertise that they can leverage to execute profitable trades based on private information. Thus, if having less publicly available information increases the incentive to acquire private information, for those users capable of profitably exploiting such information, the opacity of firms' financial reporting is likely to be an important factor in determining the extent of informed trade.

I explore the relation between opacity and institutional informed trading in a threephase empirical analysis using a broad sample of cross-country data on trading by international mutual funds. First, to establish whether opacity significantly affects the extent of informed institutional trade, I examine the relation between firm- and country-level financial reporting and the extent to which changes in institutional holdings predict future returns. Second, to provide deeper insight into the cross-sectional determinants of the association between opacity and informed trade, I examine variation in the relation across 
varying country-level disclosure regimes and types of institutional investor. Finally, to assess the economic significance of these results, I conduct a difference-in-differences analysis.

In the first analysis, I find that changes in institutional holdings are more positively associated with future returns for firms with greater opacity as measured by analyst following, forecast accuracy, forecast diversity, auditor choice and discretionary earnings smoothing. I also find evidence of more informed trading in firms located in countries with a less developed and extensive news media, weaker country-level disclosure and worse corporate governance. These results establish that firm- and country-level opacity are individually and incrementally important determinants of the extent of institutional informed trading. Further, my results also indicate a strong interactive relation between firm- and country-level opacity. I find that the association between informed trade and firm-level opacity is strongest where the country-level disclosure environment is weakest and diminishes significantly in countries with more developed disclosure regulation and information dissemination. This result demonstrates that, while an opaque country-level disclosure regime appears to complement firm-level opacity and encourage more private information-based trading, a more transparent country-level infrastructure provides alternate sources of information which may mitigate the effects of poor firm-level disclosure.

Next, I examine whether the association between opacity and informed trade varies based on institutional investor characteristics. I find that firm-level opacity is more strongly related to the extent of informed trade for institutions domiciled in the same country as their target firms ("local”) relative to institutions domiciled in different countries than their target firms (“foreign”) and for institutions with high portfolio turnover ("transient”) relative to institutions with low portfolio turnover (“dedicated”). Moreover, splitting local relative to 
foreign and transient relative to dedicated institutional trading based on the opacity of the country-level information environment, I find that the association between firm-level opacity and informed trade is strongest among local and transient institutions investing in firms domiciled in countries with relatively more opaque infrastructures. These findings indicate that firm- and country-level opacity provide the greatest benefit to those investors for whom the incentives and opportunities to acquire private information are strongest.

Finally, I use a difference-in-differences analysis to assess the economic importance of my primary findings. I find that the annualized risk-adjusted returns for opaque firms with the largest change in institutional holdings are 5.8\% larger than those of firms with the smallest change. This difference increases to $6.5 \%$ when both firm- and country-level opacity are considered. The difference in returns across change in holdings groups for transparent firms are significantly smaller suggesting that institutions are better at predicting the returns of opaque firms. Moreover, I document that these returns are likely to exceed transactions costs for most firms in my sample, indicating that some institutions can earn significant gross profits from private information-based trading in opaque firms. ${ }^{3}$

I also conduct an extensive set of additional tests and sensitivity analyses to show my results are robust to the inclusion of firm fixed effects, several alternative constructions of my primary measure of informed trading and a variety of additional controls for liquidity and risk factors found by prior research to be associated with future returns. Results are also consistent within the vast majority of sample countries and years.

\footnotetext{
${ }^{3}$ These results suggest that institutions' trades in opaque firms are profitable on a gross basis and exceed one measure of transactions costs. However, without a measure of the cost of effort institutions expend acquiring private information, it is difficult to determine the profitability of their trades net of all costs. Nevertheless, the magnitude of the positive gross return I document suggests that institutions are rewarded for the effort they expend investing in opaque stocks.
} 
My study makes several contributions to the existing literature. First, my paper provides novel evidence that the opacity of a firm's information environment, at both the firm- and country-level, is a statistically and economically significant determinant of the extent of informed trading by institutional investors. Second, my paper provides additional insight into the relation between opacity and institutional informed trade by demonstrating that the extent of informed trading is significantly influenced by interactive relations between firm-level financial reporting and: the country-level disclosure regime and investors’ incentives and opportunities to acquire private information. Finally, in contrast to the extant research on the economic effects of financial reporting, my paper is the first (of which I am aware) to provide direct evidence that some classes of sophisticated investors may actually benefit from more opaque financial reporting.

\section{Prior Literature}

My primary interest is examining whether the opacity of firms' financial reporting environments is a significant determinant of the extent of informed trading by institutional investors. Prior research on institutional informed trading focuses mainly on whether and, to a lesser extent, what types of institutions are likely to make profitable trades based on private information. We know little about how opacity affects traders' abilities to earn these excess returns. The prior literature examining the economic effects of financial reporting in equity markets focuses on the ways in which the average investor benefits from a richer information environment. There is, to my knowledge, no direct research on the potential for sophisticated arm's length investors, such as institutions, to benefit from financial reporting opacity. Nonetheless, several streams of literature provide economic background and help motivate the predictions of my study. 
The first related literature examines whether institutional investors possess superior information about firms' future performance. For example, Ali et al. (2004) finds a positive association between changes in aggregate institutional ownership and abnormal returns at the time of the subsequent earnings announcement, consistent with some institutions making informed trades. Ke and Petroni (2004) finds an association between changes in aggregate institutional ownership and breaks in strings of quarterly earnings growth. My paper differs from this literature because it focuses not on whether institutions are superiorly informed, but rather on how the opacity of a firm's information environment affects the extent of informed trade. Further, unlike prior papers in the literature, my paper provides additional insight into how interactive relations between firm-level financial reporting opacity and the country-level disclosure regime and investors' incentives and opportunities to acquire private information affect the extent of institutional informed trading.

A second related literature examines how regulations intended to limit the selective disclosure of nonpublic information affect insider trading. For example, Ke et al. (2008) finds that selling prior to breaks in strings of consecutive earnings increases by investors with conference call access to management decreased following the implementation of Regulation FD. Ke et al. (2008) attributes this finding to a decrease in privileged access to management. My paper differs from this literature because it focuses on how firms' public disclosures affect the extent of informed trading rather than on the effects of regulating access to inside information.

The third related literature examines whether characteristics of the institutions themselves explain the extent of profitable private information-based trading. Bushee and Goodman (2007) shows informed trading by institutions is most likely to take place when 
institutions hold large positions in particular firms, when the institution itself is large, and when the institution has more lax fiscal responsibilities. Baik et al. (2010) shows, in the U.S., informed trading is concentrated primarily among local (in terms of geographic proximity) institutions. Yan and Zhang (2009) argues that the positive relation between institutional ownership and future stock returns documented in Gompers and Metrick (2001) is driven by short-term investment horizon investors. My study focuses instead on attributes of the target firms and complements this literature by demonstrating that an opaque financial reporting environment benefits most those investors with the greatest abilities, incentives and opportunities to exploit private information.

The final stream of related research examines the association between firms' information environments and information asymmetry. Using a sample of U.S. firms, Brown and Hillegeist (2007) demonstrates that higher AIMR transparency scores are associated with lower values of the Easley et al. (2002) probability of informed trade measure, PIN. Internationally, Leuz and Verrecchia (2000), Daske et al. (2008), Lang et al. (2011) and others show that greater firm-level financial reporting transparency is associated with lower bid-ask spreads and higher liquidity. Although these findings are informative, a negative association between transparency and information asymmetry does not necessarily imply that some investors might actually benefit from less public disclosure. I show that certain subsets of institutional investors may be able to exploit opacity to create a tradable information advantage. Further, these studies offer little insight into the identity and characteristics of the superiorly informed parties. My paper uses data at the investor level, as well as the firm level, to provide direct evidence that financial reporting opacity is associated with the informational advantages of sophisticated investors. 


\section{Empirical Predictions}

Although I do not view it as a test of a particular theory, my analysis is motivated by the intuition underlying papers such as Verrecchia (1982) and Diamond (1985), which theoretically model how public disclosure affects incentives to acquire private information. A common theme is that the amount of costly private information investors choose to acquire is decreasing in the amount of information firms disclose publicly. Building on this prior work, I make four specific empirical predictions. The first addresses whether financial reporting opacity is a significant determinant of the extent of informed trading, the remaining three focus on where and for whom an opaque information environment is likely to provide the greatest benefit for private information-based trading. Together, these predictions, and the empirical analyses thereof, are intended to provide an in-depth assessment of the relation between financial reporting opacity and institutional investors' ability to acquire and exploit informational advantages.

Kim and Verrecchia (1997) shows that an investor's demand for a stock is a function of the precision of her private information. In the Kim and Verrecchia (1997) model, investors with more precise information prior to an anticipated public announcement take positions before the disclosure occurs and make trades that are positively associated with future returns. Coupled with the Verrecchia (1982) and Diamond (1985) theories, which suggest that higher opacity may increase the profitability of informed trading, these arguments imply that having a more opaque information environment creates a greater incentive for investors to acquire private information in advance of future information 
releases. Trades based on such private information create a positive correlation between changes in holdings and future performance. ${ }^{4}$

Despite the incentives created by the absence of public disclosure, acquiring private information is costly. A positive correlation between changes in holdings and future returns arises only if the benefits of exploiting private information exceed the costs of acquisition. I expect that in the face of scant publicly available information, for investors with significant expertise and access to resources, the benefits of informed trade are likely to outweigh the costs. My first empirical prediction is that the magnitude of the positive association between changes in institutional holdings and future returns is increasing in the opacity of firms' financial reporting.

Prior research suggests that the implications of firm-level opacity vary based on the quality of the disclosure environment in the country where the firm is domiciled [e.g., Lang and Maffett (2011b)]. While weak country-level disclosure regulations may further increase opacity and thus the potential benefit of private information acquisition, a more developed country-level information dissemination infrastructure, such as, for example, an expansive news media, may serve as a substitute for limited firm-level information. My second empirical prediction is that the association between institutional informed trade and firmlevel opacity is increasing in the opacity of the country-level disclosure environment.

\footnotetext{
${ }^{4}$ A reasonable question is why uninformed investors are willing to purchase opaque stocks knowing they may face informed trading. Kyle (1985) argues that traders price protect by demanding higher returns to hold assets with greater information risk and thus, even with asymmetric information, may optimally include such assets in their portfolios. Further, assuming traders cannot directly observe whether the counter-party is informed, they do not know whether they are trading against an informed party, only that the information risk is high.
} 
Even among institutional investors, it is unlikely that the ability to acquire and profitably exploit private information is uniformly distributed. Prior research, as discussed in Section 2, indicates that informed trade is most prevalent among (or limited to) those institutions with the greatest ability to acquire private information. Models such as Dumas et al. (2011) suggest local investors are better positioned to acquire private information than foreign investors and thus are most likely to benefit from opacity. Empirically, Leuz et al. (2010) find that foreign investors invest less in firms that reside in countries with weak governance and opaque financial reporting. Leuz et al. (2010) attribute this finding to higher information asymmetry and monitoring costs faced by foreign investors. My third empirical prediction is that the relation between informed trade and opacity is stronger for local relative to foreign institutions.

Finally, Yan and Zhang (2009) finds that the positive relation between institutional ownership and future stock returns documented in Gompers and Metrick (2001) is driven by short-term investors and argues that this finding is consistent with these investors being better informed and trading more frequently to exploit their informational advantages. This suggests short-term investors may more actively seek to acquire private information. As discussed previously, such information is likely both more prevalent and more profitable in opaque information environments. My fourth empirical prediction is that the relation between informed trade and opacity is stronger for transient relative to dedicated institutional investors.

\section{Research Design}


To test my empirical predictions, I estimate a series of pooled OLS regressions of the following general form:

$$
\begin{aligned}
\text { Informed Trade }_{i, t} & =\alpha_{0}+\beta_{1}{\text { Control } \text { Variables }_{i, t-1}} \\
& +\beta_{2} \text { Opacity Characteristics }_{i, t-1}+\text { Fixed Effects }+\varepsilon_{i, t}
\end{aligned}
$$

Informed Trade is the average level of informed trading by all institutions investing in firm $i$ in year $t$. I describe the calculation of Informed Trade in detail, along with the control variables and opacity characteristics, in the following sections. To mitigate concerns about endogeneity, I measure each of the control variables and opacity characteristics with a lag. In analyses where the variables of interest are measured at the firm level (country level), I cluster standard errors at the firm level (country level) to account for possible correlation in residuals. To reduce the influence of extreme observations, I winsorize all continuous nonlogarithmic variables at the $2.5 \%$ level, unless otherwise noted.

\subsection{Measuring informed trading by institutional investors}

Kim and Verrecchia (1997) shows that pre-announcement trades made by investors with private information are positively associated with future changes in firm value. According to this argument, a positive association between changes in ownership and subsequent stock returns provides evidence of informed trading. Drawing on this theoretical motivation, an extensive empirical literature uses the beta coefficient from a regression of future returns on changes in institutional holdings as a basis for assessing the extent of informed trading [e.g., Ali et al. (2004); Yan and Zhang (2009)]. ${ }^{5}$ I follow this prior

\footnotetext{
${ }^{5}$ A potential disadvantage of this measure of informed trading is that prices may impound investors' private information immediately at the time of the trade (or shortly thereafter during the reporting period over which changes in holdings are measured) rather than over the subsequent 90 days. However, there are several reasons to expect that prices will not fully reveal informed investors' private information immediately. First, if prices
} 
theoretical and empirical literature in constructing my measure of informed trade. ${ }^{6}$ I also include controls for prior and contemporaneous returns when estimating the extent of informed trade. Although these variables are unlikely to be correlated with future returns in an efficient market, because prior literature finds that institutions follow positive feedback trading strategies and exert price pressure on returns, they are likely to be correlated with changes in institutional holdings [e.g., Sias et al. (2006)]. Prior research suggests including such variables on the right-hand side to control for measurement error in the independent variable of interest [e.g., Collins et al. (1994)].

Specifically, I estimate the extent of informed institutional trading by firm-year using regressions of the following form:

$$
A B H R_{i, t+90}=\alpha_{0}+\beta_{1} \Delta I H_{j, i, t}+\beta_{2} A B H R_{i, t-1-90}+\beta_{3} A B H R_{i, t}+\varepsilon_{j, i, t}
$$

$A B H R$ is the risk-adjusted buy-and-hold return for firm $i$ less the buy-and-hold return for the market in firm i's country of domicile. ${ }^{7} \Delta I H$ is the change in percent of total shares held by institution $j$ in firm $i$ from time $t-1$ to $t .^{8}$ I require at least 10 observations to estimate the

incorporated investors' private information immediately, gains from these trades would be significantly reduced. For this reason, informed investors have a strong incentive to break-up or otherwise disguise their trades to minimize price impact [Bushee and Goodman (2007)]. In support of this argument, Campbell et al. (2004) find that institutions trade in very small lot sizes. Second, speculating based on private information is risky giving risk adverse investors an incentive to delay their profit realization until their private information is publicly revealed.

${ }^{6}$ I model future returns as a function of changes in institutional holdings so that information unrelated to informed trading that affects future returns is included in the error term of Equation (2). If I instead estimate changes in holdings as a function of future returns, results throughout the paper are very similar.

${ }^{7}$ I calculate market buy-and-hold returns within sample using all available firms in a particular country. I require at least 10 firms per country over the return accumulation period ( $t$ to $t+90)$.

${ }^{8}$ Institutional holdings reporting intervals range from 3-6 months and, while there is some clustering of reporting around calendar-quarter-end dates (14\% of the institutions report in March, 20\% in June, 14\% in September and 23\% in December), a significant portion of the funds report during the other months of the year. 
regression for each firm-year. I calculate firm and market buy-and-hold returns over three distinct windows: 1) over the 90-calendar-day window preceding the institutional holdings reporting period, $t-1-90$; 2 ) over the institutional holdings reporting period, $t$; and 3) over the 90-calendar-day window following the institutional holdings reporting period, $t+90$. Before estimating Equation (2), I risk-adjust returns following the approach in Pincus et al. (2007) which is motivated by the variables shown in Fama and French (1998) to be associated with future abnormal returns in an international context. As suggested by Sias et al. (2006), I also include prior year returns to control for momentum. Specifically, I calculate risk-adjusted returns by regressing abnormal returns on the firm's decile rank for size, prior year return, the book-to-market ratio and the earnings-to-price ratio and use the resulting residual values as my measure of risk-adjusted returns. Appendix A includes a timeline of when each of the variables in Equation (2) is measured.

The resulting $\beta_{1}$ coefficient from Equation (2) provides a firm-year specific measure of the average correlation between future returns and changes in institutional holdings. Positive values of this coefficient indicate that institutions are able to forecast future performance and thus provide evidence of informed trade. Since my interest is in explaining variation in informed trade, and also to control for extreme observations, I constrain $\beta_{1}$ to lie between $[0,1]$. I apply this constraint by setting those observations that fall below zero (42.1\%) equal to zero and those observations that exceed one (0.4\%) equal to one, so that zero represents uninformed trade and one represents the most informed trading. ${ }^{9}$ I take the resulting value as my primary measure of informed trading by institutions, Informed Trade. ${ }^{10}$

\footnotetext{
${ }^{9}$ The finding that $\beta_{1}$ is negative for approximately $42 \%$ of my sample is consistent with prior literature [e.g. Bushee and Goodman (2007) and Cai and Zheng (2004)] which finds mixed evidence of informed trading by
} 


\subsection{Measuring Firm-Level Opacity}

Because opacity is inherently difficult to measure, I use five separate indicators for the availability of firm-specific information. ${ }^{11}$ The first is the number of analysts issuing a forecast of the firm's fiscal year earnings, Analyst Following. Lang et al. (2004) provides evidence that, in an international setting, analysts play an important oversight and information-processing role and thus a smaller Analyst Following is taken to be indicative of greater opacity.

In addition to the number of analysts following a firm, greater accuracy of their forecasts also likely reflects greater transparency of the firm’s information environment. Lang and Lundholm (1996) suggests forecast accuracy captures both the information acquisition activities of analysts as well as the disclosure policies of firms. I use Forecast Accuracy as my second measure of firm-level opacity, where lower levels of Forecast Accuracy indicate higher levels of opacity. Relatedly, Jin and Myers (2006) shows that the extent to which analysts’ forecasts differ from one another (i.e., their forecast diversity) is proportional to the standard deviation of hidden firm-specific information. I use Forecast

\footnotetext{
the average institution. As discussed further in Section 5.4, I conduct several robustness tests, including using a Tobit regression approach, unconstrained values of $\beta_{1}$ and including only positive values of $\beta_{1}$, to ensure that the concentration of observations at zero does not affect my results.

${ }^{10}$ Because I can identify only one side of each trade, my informed trading measure is subject to several limitations. First, by design, it cannot detect institutions' informed trading against other institutions included in my sample. Second, it is unclear how to interpret negative associations between changes in holdings and future returns in terms of the extent of informed trade. However, these issues are unlikely to be a significant concern as the focus of my paper is on examining potential determinants of informed trading as evidenced by a positive association between changes in institutional holdings and future returns.

${ }^{11}$ Throughout the remainder of the paper, for parsimony, I omit detailed variable definitions. Detailed descriptions of all variables, noted in italics, can be found in Appendix B.
} 
Diversity as my third measure of firm-level opacity, where higher Forecast Diversity indicates greater opacity.

Whether or not management chooses a high quality external auditor of its financial statements may also provide an indication of the firm's commitment to financial reporting transparency. Prior research such as Teoh and Wong (1993) and DeFond and Jiambalvo (1993) suggests ‘Big-5’ auditor oversight is associated with higher quality accounting data. Accordingly, I use an indicator variable for whether the firm uses a 'Big-5' auditor as my fourth measure of firm-level opacity, where absence of a Big-5 Auditor is taken to be indicative of greater opacity.

An extensive literature in accounting shows that firms with earnings that exhibit less earnings management are likely to have higher quality accounting and therefore exhibit greater transparency. One commonly used class of measures seeks to capture the smoothness of the firm's earnings stream. The idea underlying these measures is that insiders can conceal their firm's performance by reducing the variability of reported earnings through the manipulation of accruals (i.e., smoothing). Prior research in an international context, such as Leuz et al. (2003) and Lang et al. (2011), suggests greater discretionary earnings smoothing is associated with greater opacity. For my final measure of opacity, I use Discretionary Smoothing as calculated in Lang et al. (2011).

\subsection{Measuring Country-Level Opacity}

In addition to firm-level measures, I also investigate the relation between three separate country-level measures of opacity and the extent of informed trade (country-level values for each of these measures are reported in Table 1). Bushman et al. (2004) shows that 
the lack of a well-developed media communication infrastructure limits the flow of firmspecific information to interested parties. For my first measure of country-level opacity, I follow Bushman et al. (2004) and construct a measure of media development, Media Penetration, from the World Bank’s World Development Indicators database based on newspaper circulation, television ownership and internet connections per capita from 1994 to 2004. A lower Media Penetration ranking indicates greater opacity.

For my second measure of country-level opacity, Disclosure, I use a measure of financial disclosure requirements from La Porta et al. (2006). A long line of literature, beginning with La Porta et al. (1997), documents that country-level required disclosure intensity is an important determinant of a firm's information environment. Lower Disclosure scores indicate greater opacity.

For my third country-level measure of opacity, I use the governance disclosure measure from Bushman et al. (2004), Governance. Bushman et al. (2004) shows that the quality of a country's corporate governance infrastructure is an important determinant of corporate reporting transparency. Lower Governance scores indicate greater opacity.

Overall, use of the various firm- and country-level opacity measures allows me to examine a variety of aspects of firms’ public disclosure environments. However, it is important to note that there are likely to be differences among the measures with respect to how the uncertainty they reflect is ultimately resolved. A necessary condition for the realization of informed trading profits is that the private information that serves as the basis for the informed investor's position ultimately becomes public and is incorporated into prices. Measures that primarily reflect an opaque voluntary disclosure environment, (i.e., 
Forecast Accuracy, Forecast Dispersion and Disclosure) as well as those that reflect limited information production by outsiders (i.e., Analyst Following and Media Penetration), create uncertainty about the firm's performance that can be resolved through mandated firmspecific disclosures. Other measures such as Discretionary Smoothing and Big-5 Auditor are direct measures of specific ways that a firm can obscure its performance and the quality of its reported financial information. It is less clear that firm-specific disclosures can resolve such uncertainty. Rather, it is more likely that information obscured by low quality reporting becomes public through channels outside the firm itself, such as macroeconomic reports or the financial disclosures of industry peers and customers. In an effort to capture each of these effects, in the main analyses, I use a future returns window of 90 calendar days, which should be long enough to capture both firm-specific disclosures and considerable external information revelation.

\subsection{Control Variables}

Prior literature suggests there is more informed trading in smaller, younger, more volatile and higher growth firms [Bushee and Goodman (2007); Baik et al. (2010)]. To ensure the effects I document are incremental to these effects, I include in Equation (1) controls for Size, Firm Age, Return Volatility and Market-to-Book. ${ }^{12}$ If a firm’s shares are rarely traded, it will be more difficult for institutions to exploit private information [Bushee and Noe (2000)]. Prior literature has also shown a firm’s liquidity to be an important proxy for information asymmetry [e.g., Lang et al. (2011)]. I include Turnover to control for these effects. Prior research shows firms with a U.S. ADR have higher institutional holdings and

\footnotetext{
${ }^{12}$ A firm's idiosyncratic return volatility could also serve as a measure of information incorporation into price [e.g., Jin and Myers (2006)]. For this reason, the predicted sign on Return Volatility is ambiguous.
} 
greater transparency [Lang et al. (2003)]. To control for these effects, I include an indicator variable for whether the firm cross-lists shares in the U.S., $A D R$.

Further, Informed Trade is also likely to be a function of the level of institutional holdings. Two competing effects are possible. First, if institutions can profitably exploit private information in some firms, they may tilt their portfolios toward such firms.

Alternatively, because I can identify only one side of each trade, Informed Trade will not detect institutions trading against other institutions simultaneously included in estimations of Equation (2) and may be decreasing in the level of institutional holdings. I include a control for the percentage of institutional holdings, Institutional Holdings, in all analyses to control for these effects. Finally, I include country, industry and year fixed effects in all tests using firm-level measures of opacity and country, industry and year random effects in analyses using country-level measures.

\section{Sample and Results}

\subsection{Sample Selection and Descriptive Statistics}

I compile data for the analyses from the intersection of the Thompson Reuter's International Mutual Fund (TIMF) and Datastream Advance (Datastream) databases. ${ }^{13}$ The TIMF database reports quarterly firm-level holdings data for over 45,000 global mutual funds located in 63 countries from 1999 through $2009 .{ }^{14}$ To be included in the sample, I require firm-year observations to, at a minimum, have holdings data from TIMF, analyst data from

\footnotetext{
${ }^{13}$ Several prior papers including Hau and Rey (2008), Chan et al. (2005) and Yu (2010) have used, and discuss in further detail, the TIMF database.

${ }^{14}$ According to a representative, Thomson gathers data both directly from the mutual funds themselves as well as from agents of the local authorities. TIMF does not report mutual fund holdings in U.S. domiciled firms.
} 
I/B/E/S, and market data to compute the primary control variables from Datastream. I exclude any country with less than 100 firm-year observations.

Table 1 Column (1) provides a breakdown of the sample mutual funds by country. Overall, my sample contains data for 42,930 different mutual funds from 42 countries. The United States, Germany, Spain and the United Kingdom have the largest number of distinct funds, while the remaining funds are relatively well dispersed among the other 38 countries. Table 1 Column (3) provides a breakdown of the sample firm-years by country. In total, my sample contains 43,290 firm-year observations from 38 countries. An advantage of this broad international sample is that it is not dominated by the largest most heavily followed international firms. As a result, it contains a substantial number of firms for which opacity issues are likely to be more pronounced. The substantial variation among the funds and firms within the sample should increase the power of my tests.

Table 2 provides descriptive statistics for variables used in the regression analyses. Median informed institutional trading (Informed Trade, multiplied by 100 for readability) is 0.001, indicating that, for the median firm, changes in institutional holdings have a relatively small positive association with future returns. In terms of the control variables, the descriptive statistics indicate that the sample firms are medium-sized on average and range from very large to much smaller firms (Size). The median firm has been publicly-traded for almost twelve years (Firm Age), has an annualized volatility of 35.9\% (Return Volatility), has a market value in excess of its book value (Market-to-Book), turns over its shares about every two years (Share Turnover), does not trade shares on a U.S. exchange (ADR) and has mutual fund ownership of 8.7\% (Institutional Holdings). Looking next at the firm-level opacity 
proxies, the median firm is followed by four analysts (Analyst Following) and does not have financial statements audited by a ‘Big-5’ accounting firm (Big-5 Auditor).

Table 3 presents correlation matrices for the primary variables of interest, with Pearson correlation coefficients above the diagonal and Spearman coefficients below the diagonal. Most of the firm- and country-level opacity characteristics are significantly correlated (in the predicted direction), which suggests they capture a shared underlying economic construct. None of the correlations for any simultaneously included variables exceeds 0.53 (between Size and Analyst Following) indicating multicollinearity is unlikely to be an issue in the regression analyses.

\subsection{Analysis of Informed Trading by Institutions and Firm-Level Opacity}

My first empirical prediction is that the magnitude of the association between future returns and changes in institutional holdings is increasing in the opacity of firms' financial reporting environments. Table 4 presents results for tests of this prediction using five separate firm-level measures of opacity. In this analysis, I use fixed effects to hold static year-, industry- and country-level factors constant, which allows me to focus explicitly on how firm-level variation in opacity within a particular country, industry and year affects informed institutional trading.

In terms of the control variables, I find larger firms (Size) with higher market-to-book ratios (Market-to-Book), greater turnover (Turnover) and higher institutional holdings (Institutional Holdings) experience significantly less informed trading, while more volatile (Return Volatility) firms experience more. 
Moving next to my primary relations of interest, I find that each of the five firm-level opacity indicators are significantly associated with informed trade in the predicted direction [Columns (1)-(5)]. Looking first at the analyst characteristics, Analyst Following and Forecast Accuracy are both significantly negatively associated with Informed Trade. The association between Forecast Diversity and Informed Trade is significantly positive. These results suggest that oversight and information acquisition by analysts are associated with a decrease in informed trading. Big-5 Auditor is negative and significant, indicating that selection of a high-quality auditor is associated with a decrease in private information-based trading. Finally, Discretionary Smoothing is significantly positive, indicating that informed trading by institutions is greater when managers report earnings that are excessively smoothed relative to underlying cash flows.

Column (6) of Table 4 reports results simultaneously including each of the five opacity proxies. To increase the sample size for this analysis, I set missing values of Forecast Diversity and Discretionary Smoothing equal to the country-specific median. Analyst Following, Forecast Accuracy, Big-5 Auditor and Discretionary Smoothing are each incrementally significantly associated with Informed Trade, while Forecast Diversity is no longer statistically significant. This result indicates that, although the measures are unlikely to be independent (e.g., auditor quality likely influences the extent of discretionary smoothing and analyst forecast accuracy), the majority have significant incremental explanatory power. Nonetheless, the positive correlations among the variables (see Table 3) suggest that each of the five firm-level measures capture a shared underlying construct. For this reason, and for parsimony going forward, I combine the opacity measures by ranking each variable and summing the percentile ranks to compute an aggregate opacity measure, 
Firm-Level Opacity. ${ }^{15}$ Column (7) reports results for the aggregate opacity measure, which is, as expected, significantly positively associated with Informed Trade.

Overall, the results of the firm-level opacity and informed trading analysis support my first empirical prediction that the magnitude of the association between changes in institutional holdings and future returns is increasing in firm-level financial reporting opacity.

\subsection{Analysis of Informed Trading by Institutions and Country-Level Opacity}

In the prior analysis, I controlled for fixed country-level effects and showed a positive association between firm-level opacity and informed trading. However, the extent of informed trading also likely varies based on country-level proxies for the opacity of the firm's information environment. The next analysis provides further tests of my first empirical prediction using three separate country-level measures of opacity.

Table 5 reports the results of the country-level opacity analysis. In this analysis, I control for country random effects to ensure that other country-level factors (e.g., GDP) which may be correlated with my county-level measures of opacity do not confound my inferences. To ensure any potential country-level effects are incremental to the firm-level effects documented in Table 4, I also include Firm-Level Opacity as an additional control variable. Results for each of the control variables, including Firm-Level Opacity, are consistent with the findings in Table 4. In terms of the primary variables of interest, in Columns (1)-(3), I find Media Penetration is significantly negatively associated with Informed Trade, indicating that information-based trading by institutions is lower in

\footnotetext{
${ }^{15}$ To preserve sample size, I require only that Analyst Following and Forecast Accuracy be available to compute the aggregate Firm-Level Opacity measure. If Forecast Diversity, Big-5 Auditor or Discretionary Smoothing is missing, the measure captures the average percentile rank of the remaining available variables.
} 
countries with more developed media communications infrastructures. In addition, both Disclosure and Governance are negatively associated with Informed Trade, which suggests that more stringent financial reporting requirements and the quality of a country's corporate governance infrastructure are important determinants of the level of informed trading.

Again, because the country-level opacity indicators are generally positively correlated (see Table 3) and likely capture a similar underlying construct, I combine the measures into an aggregate measure, Country-Level Opacity. ${ }^{16}$ Country-Level Opacity is constructed by assigning a value of one if a particular country has a Media Penetration, Disclosure, or Governance score below the sample median and summing the score for each country. As constructed, Country-Level Opacity ranges from zero to three, with three representing countries with the most opaque reporting and zero representing countries with the least. Column (5) reports results for the aggregate country-level opacity measure, which is, as expected, significantly positively associated with Informed Trade.

To summarize, the results of this section further support my first empirical prediction that informed trading by institutional investors is increasing in the opacity of the countrylevel financial reporting environment.

\subsection{Additional Analyses and Robustness Tests}

In this section, I discuss the results of several additional analyses and robustness tests designed to increase confidence in the interpretation of my results. First, to ensure censoring of Informed Trade at zero does not unduly influence my results, I estimate Equation (1) as a

\footnotetext{
${ }^{16}$ Because of high multicollinearity among the country-level opacity proxies, I do not estimate their effects simultaneously. However, I do address each variable’s incremental importance in Section 5.5.
} 
Tobit regression. Column (1) of Table 6 presents results for this alternative specification, where I find Firm-Level Opacity remains significantly positively related to Informed Trade.

Second, to alleviate concerns that the variable's skewness (caused in part by censoring at zero) biases my results, I estimate Equation (1) using the percentile rank of Informed Trade. Results for this analysis, presented in Column (2) of Table 6, confirm the association between Firm-Level Opacity and Informed Trade is robust to this alternative specification.

Third, to both address the possibility of a risk-based explanation and to increase confidence that the documented association between changes in institutional holdings and future returns is attributable to trading based on information about future performance, I repeat my primary analyses replacing $A B H R$ in Equation (2) with three-day cumulative abnormal earnings announcement returns (EACAR3). I use actual earnings announcement dates from $I / B / E / S$ (retaining only announcements within one quarter (90 days) of the institutional holdings report date) and calculate cumulative abnormal returns during the three-day window around these dates. Column (3) of Table 6 presents results using EACAR3.$^{17}$ Although sample size is reduced significantly in this analysis (from 43,290 to 6,335), reflecting both the limited availability of earnings announcement data for international firms and the restriction that the announcement be within one quarter of a holdings report, I continue to find Firm-Level Opacity is significantly positively associated with Informed Trade. Moreover, the larger coefficient on Firm-Level Opacity (relative to the main specification) suggests that a disproportionate share of institutional investors' private

\footnotetext{
${ }^{17}$ Because the reduction in number of observations leads to noisier estimates, for this analysis, Informed Trade is winsorized at the $5 \%$ level. Results are consistent, but weaker, winsorising at $2.5 \%$ or $1 \%$.
} 
information is revealed during this relatively short window. The short window of the earnings announcement returns also provides additional assurance that changes in risk are unlikely to drive the observed association between opacity and informed trade.

Fourth, I consider an Informed Trade measure based on an unconstrained $\beta_{1}$ coefficient. ${ }^{18}$ As discussed in Section 4, in calculating Informed Trade, I constrain the $\beta_{1}$ coefficient from Equation (2) to lie between [0,1]. While my primary interest is in investigating informed trade, as evidenced by a positive association between changes in institutional holdings and future returns, it is possible that variation within the negative range of the $\beta_{1}$ coefficient also has meaningful explanatory power. Column (4) of Table 6 presents results for this analysis. While Firm-Level Opacity remains significantly positive in this alternative specification, the adjusted- $\mathrm{R}^{2}$ decreases, as does the significance of several of the control variables, suggesting that the unconstrained $\beta_{1}$ coefficient is not as precise a measure of informed trading as is the constrained coefficient. In an untabulated analysis, I also confirm that results are robust to excluding negative values of $\beta_{1}$ entirely.

Fifth, I include a control for bid-ask spread. Prior literature shows that firm-level opacity is positively associated with a stock's illiquidity, as captured by proxies such as the bid-ask spread [e.g., Lang et al. (2011)]. To ensure the association between opacity and informed institutional trading I document does not simply reflect a correlation between Informed Trade and illiquidity, in Column (5) of Table 6, I include Spread as an additional control variable. The results show that, although Spread is significantly positively associated

\footnotetext{
${ }^{18}$ Rather than censoring, to control for outliers in this specification, I winsorize $\beta_{1}$ at the $5 \%$ level. Results are consistent, but weaker, winsorising at $2.5 \%$ or $1 \%$.
} 
with Informed Trade, the Firm-Level Opacity coefficient remains positive and significant, indicating that the association between opacity and informed institutional trading is distinct from the association between opacity and illiquidity documented in prior literature.

Sixth, I consider a model including firm fixed effects. The primary firm-level analyses include country, industry and year fixed effects and standard errors clustered at the firm level, but it is possible other firm-specific factors could be important as well. A concern with including firm fixed effects is that several of the opacity proxies (i.e., Big-5 Auditor and Discretionary Smoothing) are constructed either over a several year window or change very infrequently. Despite the stickiness of the opacity characteristics, results including firm fixed effects, presented in Column (6) of Table 6, are consistent with those presented previously, providing additional assurance that unmodeled firm-level factors are unlikely to drive the observed association between opacity and informed trade.

Seventh, I consider a changes specification. While the firm fixed effects analysis controls for static firm-level effects, an analysis based on first differences explicitly focuses on time-series covariation between the variables. As with my primary analyses, I measure the change in Firm-Level Opacity one year prior to the change in Informed Trade. Column (7) of Table 6 presents results for this analysis. The coefficient on Firm-Level Opacity remains positive and significant, providing further comfort that my results are not driven by omitted firm-level variables. ${ }^{19}$

Finally, because it represents a significant portion of the sample (>20\%), I repeat the prior analyses eliminating Japanese firms. Results (untabulated) are robust to excluding

\footnotetext{
${ }^{19}$ Because there is no variation in the change in Firm Age from year to year, I omit it as a control in the firm fixed effects and changes analysis.
} 
Japanese firms. Moreover, results are robust to excluding any other individual country from the sample. In fact, repeating the analysis within each of the 38 countries, the coefficient on Firm-Level Opacity is positive in 32 countries [14 significantly (two-tailed); 18 significantly (one-tailed)] and is never significantly negative. Repeating the analysis within each of the ten years in the sample, the coefficient on Firm-Level Opacity is significantly positive in nine out of ten years. Overall, these results confirm the consistency of my primary findings across a wide range of countries and time periods.

\subsection{Analysis of Firm- and Country-Level Opacity Interactions}

In this section, I investigate whether firm- and country-level opacity have an interactive effect on informed trading. Prior research suggests that while an opaque countrylevel disclosure regime can exacerbate firm-level opacity, more extensive country-level disclosure regulation and information dissemination can mitigate the effects of poor firmlevel reporting [e.g., Lang and Maffett (2011b)]. To investigate this possibility, as well as to assess the incremental importance of the individual country-level opacity proxies, I examine the strength of the relation between Firm-Level Opacity and Informed Trade across CountryLevel Opacity groups.

Table 7 reports results across each of the four separate Country-Level Opacity groups. From Column (1), the group of firms with the lowest scores, to Column (4), the group with the highest, I find that there is a monotonic increase in the Firm-Level Opacity coefficient. Moreover, the Firm-Level Opacity coefficient for the most opaque group of countries is over four times larger than (and is significantly different from) the coefficient for the least opaque 
group. ${ }^{20}$ This finding suggests that, while high country-level opacity may exacerbate the relation between firm-level opacity and informed trade, a strong country-level disclosure environment can have a significant mitigating effect. These results also confirm the incremental importance of each of the individual country-level opacity variables.

In summary, the results in this section are consistent with my second empirical prediction and provide evidence of a significant interactive relation between country- and firm-level opacity. This interactive effect is interesting because, although it suggests that, when combined, firm- and country-level opacity can significantly enhance the ability of institutional investors to exploit private information, it also suggests that, even when firms maintain highly opaque information environments, regulators may nonetheless be able to reduce informed trading through improvements in country-level media penetration, disclosure and governance.

\subsection{Analysis of Informed Trading and Opacity by Institutional Type}

In the next set of analyses, I investigate whether the relation between opacity and informed trading varies by type of institution. Prior empirical research suggests that certain kinds of investors have greater incentives and opportunities to acquire private information. Theory suggests private information is both more prevalent and profitable when public disclosure is limited. Together these findings suggest that the relation between opacity and informed trading will be stronger when the ability of institutions to acquire private information is greater.

\footnotetext{
${ }^{20}$ Throughout the paper, assessments of significance across subgroups are based on the p-value (one-sided) associated with firm-clustered robust standard errors of the coefficient on the interaction of Firm-Level Opacity and the partitioning variable in a fully interacted specification (i.e., I allow each variable, including the fixed effects, to vary by the partitioning variable).
} 
I use two proxies for institutions' ability to acquire private information: 1) whether the institution is foreign or local and 2) whether the institution has a long or short investment horizon. To calculate the extent of informed trading for each category of institution, I use an approach similar to the hierarchal linear modeling (HLM) technique discussed in Bushee and Goodman (2007). The HLM technique allows the extent to which informed trade is attributable to a particular institutional characteristic to be isolated by controlling for other institutional characteristics as well as interactions between those characteristics and future returns.

Specifically, to construct a measure of informed trade by type of institutional investor I estimate the following regression separately for each of the individual institutional investor characteristics (i.e., Foreign, Local, Dedicated and Transient). ${ }^{21}$

$$
\begin{aligned}
\Delta I H_{j, i, t}= & \alpha_{0}+\beta_{1} A B H R_{i, t+90}+\beta_{2} A B H R_{i, t-1-90}+\beta_{3} A B H R_{i, t}+ \\
& \delta \text { Institutional Characteristics }+ \\
& \gamma \text { Institutional Characteristics } * A B H R_{i, t+90}+\varepsilon_{j, i, t}
\end{aligned}
$$

I take the resulting $\beta_{1}$ coefficient as my primary measure of informed trading for this analysis.

For the first set of tests, I separate institutional investors into the categories of Foreign and Local based on whether the institution is located in the same or a different country as its target firm. Prior research suggests that local institutions will have an

\footnotetext{
${ }^{21}$ For consistency with the HLM approach as implemented in prior research [i.e., Bushee and Goodman (2007)], I model changes in holdings as a function of future returns when estimating informed trade across partitions based on institutional investor characteristics. Results are similar if I instead model future returns as a function of changes in holdings and account for differences in the variance of changes in holdings across the investor type partitions by standardizing the resulting $\beta_{1}$ regression coefficient.
} 
information acquisition advantage over foreign institutions [Baik et al. (2010); Dumas et al. (2011)]. Columns (1) and (2) of Table 8 Panel A present results splitting the sample based on Foreign and Local institutional investors. I find the coefficient on Firm-Level Opacity is over 40\% larger for the Local institutional group than for the Foreign group. These results suggest that institutions located in the same country as the firms in which they invest are better positioned than foreign investors to exploit opaque firm information environments through private information-based trading.

My second measure of an institution's ability to acquire private information is based on the institutions investment horizon. Prior research suggests transient institutions (i.e., those that have shorter investment horizons) are more likely to acquire and trade based on private information than dedicated (i.e., long-term investment horizon) investors [e.g., Yan and Zhang (2009)]. Bushee (2001) characterizes transient institutions as those with high portfolio turnover and highly diversified holdings. I adopt a similar approach and identify as Transient those institutions in the highest quintile of portfolio turnover and Dedicated as those in the lowest quintile. Columns (1) and (2) of Table 8 Panel B present results splitting the sample based on Dedicated and Transient institutional investors. The results show the relation between Firm-Level Opacity and Informed Trade is nearly five times as large for Transient as for Dedicated institutions. These results indicate that institutions with greater portfolio turnover profit more from informed trading in firms with high opacity than institutions with relatively long-term investing strategies. The fact that the relation between Firm-Level Opacity and Informed Trade is stronger for Transient than for Dedicated institutional investors also suggests that improvements in firm-level corporate governance, as 
discussed in Aggarwal et al. (2011) and Ferreira and Matos (2008), are unlikely to explain my findings.

I next investigate the relation between firm-level opacity and informed trade across partitions based on both investor type and the country-level information environment. The results of Section 5.5 show that the relation between Informed Trade and Firm-Level Opacity is strongest when the country-level information environment is also opaque and significantly mitigated when country-level transparency is high. This finding, coupled with the results based on institution type, suggests that institutions with the greatest incentives and opportunities to gather private information may be best able to exploit this information by investing in opaque firms that are domiciled in countries with opaque information environments. The previous results also suggest that a strong country-level disclosure and information dissemination infrastructure may limit the private information-based trading opportunities of even the most capable institutional investors.

Columns (3)-(6) of Table 8 Panel A present results splitting Foreign and Local institutional investors into High C-L Opacity (Country-Level Opacity equal to 3) and Low CL Opacity (Country-Level Opacity equal to 0) groups. Columns (3)-(6) of Table 8 Panel B report similar results splitting the sample by Dedicated and Transient. Because conclusions for these groups are very similar, for parsimony, I discuss results only for the Foreign versus Local split.

There are several comparisons of interest in Table 8 Panel A. First, the coefficient on Firm-Level Opacity is significantly larger for Local institutions in the High C-L Opacity group than for Local institutions in the Low C-L Opacity group. This result indicates that 
Local institutions are better able to exploit firm-level opacity when country-level opacity is also high. Second, the coefficient on Firm-Level Opacity is larger for Foreign institutions in the High C-L Opacity group than for Foreign institutions in the Low C-L Opacity group. This finding suggests that foreign institutions are more capable of exploiting firm-level opacity when country-level opacity is also high. Third, the coefficient on Firm-Level Opacity is significantly larger for Local institutions in the High C-L Opacity group than for Foreign institutions in the High C-L Opacity group. This implies Local institutions are better able to exploit firm-level opacity than Foreign institutions in countries with more opaque infrastructures. Finally, the coefficient on Firm-Level Opacity is larger (although not significantly) for Local institutions relative to the Foreign institutions in the Low C-L Opacity group, implying that Local institutions are better able to exploit firm-level opacity even when country-level opacity is low. These results are also consistent with the notion that, across both types of investors, a highly transparent country-level information environment mitigates the relation between informed trading and firm-level opacity.

Overall, these analyses are consistent with my third and fourth empirical predictions and demonstrate that the interactive effects between firm- and country-level opacity are particularly pronounced for those institutional investors with significant incentives and opportunities to acquire private information. Moreover, predictable variation in the strength of the association between opacity and informed trade across different types of institutions, based on the incentives those institutions have to acquire private information, increases the likelihood that my findings are attributable to a private-information-acquisition-based explanation. Specifically, because these analyses effectively hold the firm constant, potential 
alternative explanations based on unmodeled firm-specific characteristics, such as information risk, are limited and more difficult to envision.

\subsection{Difference-in-Differences Returns Tests}

In the final set of analyses, I use a difference-in-differences design to assess the potential economic importance of my main findings. To conduct this analysis, I first, on each institutional holdings report date $(t)$, separate firms into deciles based on Firm-Level Opacity. ${ }^{22}$ Then, on each institutional holdings report date $(t)$ and for each of the Firm-Level Opacity deciles, I again sort the stocks into deciles based on the total change in institutional ownership from reporting period $t-1$ to $t$. Next, I calculate the time-series average riskadjusted annualized 90-day-ahead return (from $t$ to $t+90$ ) for each of the decile portfolios. ${ }^{23}$ Then, separately for the most opaque (Firm-Level Opacity decile 10) and the most transparent (Firm-Level Opacity decile 1) firms, I calculate the difference in returns between firms with the largest increase in institutional ownership (change in holdings decile 10) and firms with the largest decrease in institutional ownership (change in holdings decile 1). The resulting difference in the change in holdings return spread across opaque and transparent firms provides an economically meaningful way to assess differences in the degree to which the trades made by institutions across these two groups appear to be informed. ${ }^{24}$

\footnotetext{
${ }^{22}$ Appendix A includes a timeline that details the timing of the measurement of both changes in holdings and future returns.

${ }^{23}$ Returns are risk-adjusted by orthogonalizing the abnormal 90-day buy-and-hold returns with respect to size, prior year return, book-to- market and earnings-to-price, as discussed in Section 4.1.

${ }^{24}$ It is important to note that a trading strategy based on changes in institutional holdings is unlikely to be implementable, as institutional holdings data are made public only with a significant lag.
} 
Table 9 presents results for the difference-in-differences returns tests. In Panel A, I find that opaque firms with the largest change in institutional holdings earn risk-adjusted returns 5.8\% larger than firms with the smallest change (p-value 0.01$).{ }^{25}$ Looking next at Panel B, I find that the change in holdings return spread for firms domiciled in countries with the most opaque infrastructures (Country-Level Opacity $=3$ ) is $4.5 \%$ (p-value 0.01 ). Next, in Panel C, I simultaneously consider both firm- and country-level opacity. These tests show that the change in holdings return spread for the most opaque firms (Firm-Level Opacity decile 10) in the most opaque countries (Country-Level Opacity = 3) is 6.5\% (p-value 0.07). I find that the change in holdings return spread for the most transparent firms (Firm-Level Opacity decile 10) is insignificant at the firm-, country- and firm- and country-levels (Panels A, B and C respectively). Further, I find that the return spreads across the opaque and transparent groups of firms are significantly different (except in Panel C), suggesting that institutions are considerably better at predicting the returns of opaque firms.

In Panels D and E of Table 9, I compare the change in holdings return spread for the most opaque decile of firms (Firm-Level Opacity decile 10) across different types of institutional investors. In Panel D, I find that for Local investors investing in the most opaque firms the change in holdings return spread is $4.4 \%$ larger than for Foreign investors investing in those same firms (p-value 0.09). In Panel E, I find that for Transient investors the return spread is $4.2 \%$ larger than for Dedicated investors (p-value 0.08). These results indicate that there is an economically significant difference across types of institutional investors in terms of their ability to exploit private information in opaque firms.

\footnotetext{
${ }^{25}$ Statistical significance within opacity deciles is based on the p-value (one-sided) of the time-series average of the difference in the 90-day portfolio returns across change in institutional holdings deciles. Statistical significance across opacity (institution-type) groups is based the on p-value (one-sided) of the time-series average of the difference in the difference of 90-day portfolio returns across the partitioning variable.
} 
Finally, to provide a basis for assessing the magnitude of the returns net of transactions costs, I note that the median bid-ask spread for the most opaque decile of firms is $1.1 \%$. While this is over twice as large as the median bid-ask spread for the most transparent decile of firms $(0.4 \%)$, it is still well below the reported return differences. The fact that the returns exceed the median transactions costs provides some indication that institutions profit from their trading in opaque firms. However, without a measure of the institution's cost of effort in acquiring private information, it is impossible to assess the return net of all costs. ${ }^{26}$

Overall, the results of the difference-in-differences returns tests indicate that the relation between opacity and informed institutional trading is of a sufficient magnitude to be economically important. Moreover, this non-parametric approach provides additional assurance that my prior results are not driven by the constraints of a linear regression specification.

\section{Conclusion}

The prior literature examining institutional trading typically focuses on whether, and what types of, institutions make profitable trades based on private information about future performance. We know significantly less about how the target firm’s public information environment affects institutional traders' ability to earn excess returns. Given their dominant role in the financial markets, a thorough understanding of the determinants of institutions' trading behavior is clearly important. This paper contributes to a deeper understanding of

\footnotetext{
${ }^{26}$ Khorana et al. (2009) finds that the total expense ratios for international mutual funds average around 2.0\% per year. Taking into account the likely magnitude of fees and transactions costs, the return magnitudes I document are comparable with Dyck et al. (2011) which documents fee-adjusted annual return outperformance for active versus passive institutional investors of approximately $2.5 \%$ in international markets.
} 
these determinants by examining how financial reporting opacity affects informed institutional trading.

Overall, my results suggest that firm- and country-level features of the public financial reporting environment significantly affect institutional investors' ability to create profitable trading advantages. My findings also demonstrate that the extent of institutional investors' informed trading is significantly influenced by interactive relations between firmlevel financial reporting and: the country-level disclosure regime and investors' incentives and opportunities to acquire private information. A difference-in-differences analysis of returns earned by institutions across opaque and transparent firms suggests these results are economically significant.

These conclusions are, of course, subject to caveats. Foremost, they do not imply causality. However, several features of my empirical design do provide some insight into the causal direction of the relation between opacity and informed trade. Foremost, reverse causality is unlikely to be an issue in this setting as it is difficult to envision a scenario in which higher levels of informed trading by institutions lead to increases in financial reporting opacity. Further, the fact that informed trade varies predictably across different types of investors and country-level disclosure environments reduces the potential alternative explanations for my results. Finally, my empirical results are consistent with the intuition underlying prior analytical research. Nonetheless, causal inferences should be drawn with caution.

Second, prior literature finds higher opacity is associated with lower liquidity and that lower liquidity can make it more difficult to disguise informed trades. In the main analyses, I 
control for the indirect effect of liquidity in order to focus on the direct effect of opacity on private information acquisition. My findings suggest that, for my sample, opacity does not constrain liquidity to such an extent that informed trading is prohibitively costly. However, it is important to note that these results may not necessarily generalize to firms where opacity is so great that the costs of transacting exceed the value of private information. 
Table 1 - Breakdown of the Sample by Country

\begin{tabular}{|c|c|c|c|c|c|c|c|}
\hline \multirow[b]{2}{*}{ Country } & \multicolumn{2}{|c|}{ Funds } & \multicolumn{2}{|c|}{ Firms } & \multirow{2}{*}{$\begin{array}{c}\text { Media } \\
\text { Penetration }\end{array}$} & \multirow[b]{2}{*}{ Disclosure } & \multirow[b]{2}{*}{ Governance } \\
\hline & $\mathbf{N}$ & $\%$ & $\mathbf{N}$ & $\%$ & & & \\
\hline Argentina & 131 & $0.4 \%$ & 119 & $0.3 \%$ & 76 & 0.50 & 68 \\
\hline Australia & 533 & $1.5 \%$ & 1,751 & $4.0 \%$ & 87 & 0.75 & 94 \\
\hline Austria & 390 & $1.1 \%$ & 291 & $0.7 \%$ & 90 & 0.25 & 79 \\
\hline Belgium & 803 & $2.3 \%$ & 583 & $1.3 \%$ & 83 & 0.42 & 76 \\
\hline Bermuda & 20 & $0.1 \%$ & - & - & - & - & - \\
\hline Brazil & 1,824 & $5.2 \%$ & 598 & $1.4 \%$ & 68 & 0.25 & 66 \\
\hline Canada & 1,674 & $4.8 \%$ & - & - & - & - & - \\
\hline Chile & 177 & $0.5 \%$ & 253 & $0.6 \%$ & 78 & 0.58 & 76 \\
\hline China & 293 & $0.8 \%$ & 666 & $1.5 \%$ & 67 & - & - \\
\hline Czech Republic & 30 & $0.1 \%$ & - & - & - & - & - \\
\hline Denmark & 387 & $1.1 \%$ & 444 & $1.0 \%$ & 91 & 0.58 & 77 \\
\hline Finland & 222 & $0.6 \%$ & 648 & $1.5 \%$ & 89 & 0.50 & 89 \\
\hline France & 3,087 & $8.8 \%$ & 2,435 & $5.6 \%$ & 80 & 0.75 & 66 \\
\hline Germany & 7,657 & $21.9 \%$ & 2,360 & $5.5 \%$ & 84 & 0.42 & 73 \\
\hline Greece & 262 & $0.7 \%$ & 635 & $1.5 \%$ & 82 & 0.33 & 66 \\
\hline Hong Kong & 640 & $1.8 \%$ & 1,897 & $4.4 \%$ & 89 & 0.92 & 91 \\
\hline Hungary & 8 & $0.0 \%$ & 125 & $0.3 \%$ & 77 & - & - \\
\hline India & 535 & $1.5 \%$ & 916 & $2.1 \%$ & 64 & 0.92 & 76 \\
\hline Indonesia & 6 & $0.0 \%$ & 436 & $1.0 \%$ & 63 & 0.50 & - \\
\hline Ireland & 237 & $0.7 \%$ & 189 & $0.4 \%$ & 80 & 0.67 & 92 \\
\hline Israel & - & - & 193 & $0.4 \%$ & 79 & 0.67 & 66 \\
\hline Italy & 1,020 & $2.9 \%$ & 1,173 & $2.7 \%$ & - & 0.67 & 66 \\
\hline Jamaica & 36 & $0.1 \%$ & - & - & - & - & - \\
\hline Japan & 1,436 & $4.1 \%$ & 10,095 & $23.3 \%$ & 95 & 0.75 & 83 \\
\hline Liechtenstein & 101 & $0.3 \%$ & - & - & - & - & - \\
\hline Luxembourg & 582 & $1.7 \%$ & - & - & - & - & - \\
\hline Malaysia & 219 & $0.6 \%$ & 1,443 & $3.3 \%$ & 76 & 0.92 & 97 \\
\hline Mexico & 162 & $0.5 \%$ & 374 & $0.9 \%$ & 73 & 0.58 & 66 \\
\hline Netherlands & 386 & $1.1 \%$ & 672 & $1.6 \%$ & 91 & 0.50 & 86 \\
\hline New Zealand & - & - & 206 & $0.5 \%$ & 90 & 0.67 & 95 \\
\hline Norway & 291 & $0.8 \%$ & 646 & $1.5 \%$ & 97 & 0.58 & 90 \\
\hline Panama & 320 & $0.9 \%$ & - & - & - & - & - \\
\hline Peru & 18 & $0.1 \%$ & - & - & - & - & - \\
\hline Philippines & 15 & $0.0 \%$ & 290 & $0.7 \%$ & 67 & 0.83 & 66 \\
\hline Poland & 84 & $0.2 \%$ & 303 & $0.7 \%$ & 75 & - & - \\
\hline Portugal & - & - & 234 & $0.5 \%$ & 83 & 0.42 & 70 \\
\hline Singapore & 382 & $1.1 \%$ & 899 & $2.1 \%$ & 90 & 1.00 & 100 \\
\hline South Africa & 363 & $1.0 \%$ & 930 & $2.1 \%$ & 65 & 0.83 & 94 \\
\hline South Korea & - & - & 711 & $1.6 \%$ & - & - & 78 \\
\hline Spain & 4,597 & $13.1 \%$ & 808 & $1.9 \%$ & 83 & 0.50 & 80 \\
\hline Sweden & 535 & $1.5 \%$ & 1,094 & $2.5 \%$ & 91 & 0.58 & 97 \\
\hline Switzerland & 1,139 & $3.2 \%$ & 1,126 & $2.6 \%$ & 92 & 0.67 & 87 \\
\hline Taiwan & 411 & $1.2 \%$ & 1,699 & $3.9 \%$ & - & 0.75 & - \\
\hline Thailand & 143 & $0.4 \%$ & 610 & $1.4 \%$ & 72 & 0.92 & 68 \\
\hline Turkey & - & - & 325 & $0.8 \%$ & - & 0.50 & 67 \\
\hline United Kingdom & 3,885 & $11.1 \%$ & 5,113 & $11.8 \%$ & 92 & 0.83 & 95 \\
\hline \multirow[t]{2}{*}{ United States } & 7,889 & $22.5 \%$ & - & - & - & - & - \\
\hline & 42,930 & $100.0 \%$ & 43,290 & $100.0 \%$ & & & \\
\hline
\end{tabular}

This table presents the country distribution of the sample mutual funds and firm-years during the period from 1999-2009 with sufficient data from the Thomson Financial International Mutual Fund and Datastream Advance databases to estimate the least restrictive specification (Model 1 for Informed Trade in Table 4). Following the Datastream convention, I refer to Hong Kong as a country. Any country with less than 100 observations is excluded. 
Table 2 - Descriptive Statistics

\begin{tabular}{lcccccc}
\hline Variable & $\mathbf{N}$ & Mean & Std & P25 & Median & P75 \\
\hline Informed Trade & 43,290 & 1.932 & 5.122 & 0.000 & 0.001 & 1.965 \\
Size & 43,290 & 13.757 & 1.933 & 12.408 & 13.547 & 14.884 \\
Firm Age & 43,290 & 0.172 & 0.122 & 0.073 & 0.142 & 0.239 \\
Return Volatility & 43,290 & 0.393 & 0.165 & 0.271 & 0.359 & 0.478 \\
Market-to-Book & 43,290 & 2.371 & 2.185 & 1.041 & 1.673 & 2.797 \\
Turnover & 43,290 & 0.929 & 1.172 & 0.238 & 0.538 & 1.099 \\
ADR & 43,290 & 0.128 & 0.334 & 0.000 & 0.000 & 0.000 \\
Institutional Holdings & 43,290 & 0.131 & 0.200 & 0.034 & 0.087 & 0.170 \\
Analyst Following & 43,290 & 6.531 & 6.518 & 2.000 & 4.000 & 9.000 \\
Forecast Accuracy & 43,290 & -0.029 & 0.061 & -0.022 & -0.007 & -0.002 \\
Forecast Diversity & 33,538 & 0.045 & 0.115 & 0.012 & 0.029 & 0.067 \\
Big-5 Auditor & 33,538 & 0.220 & 0.414 & 0.000 & 0.000 & 0.000 \\
Discretionary Smoothing & 32,605 & 0.467 & 0.250 & 0.250 & 0.475 & 0.670 \\
Firm-Level Opacity & 43,290 & 0.503 & 0.157 & 0.391 & 0.494 & 0.607 \\
Media Penetration & 39,382 & 86.341 & 9.172 & 80.333 & 90.000 & 94.667 \\
Disclosure & 41,485 & 0.710 & 0.166 & 0.583 & 0.750 & 0.833 \\
Governance & 40,061 & 83.151 & 10.450 & 76.450 & 82.610 & 93.840 \\
Country-Level Opacity & 43,290 & 1.425 & 0.986 & 1.000 & 2.000 & 2.000 \\
Spread & 29,114 & 0.012 & 0.012 & 0.004 & 0.007 & 0.014 \\
\hline
\end{tabular}

This table presents descriptive statistics for all firm-level variables included in the regression analyses, displayed in the order in which they appear, based on all firm-years between 1999 and 2009 with sufficient data to estimate the least restrictive regression model in which the data item is included. All variables are calculated as defined in Appendix A. 
Table 3 - Correlation Matrices

\begin{tabular}{|c|c|c|c|c|c|c|c|c|c|c|c|c|c|c|}
\hline VARIABLE & (1) & $(2)$ & (3) & (4) & (5) & (6) & (7) & (8) & (9) & (10) & (11) & (12) & (13) & (14) \\
\hline Informed Trade (1) & $\theta$ & -0.06 & -0.02 & 0.08 & -0.03 & -0.03 & -0.03 & -0.06 & -0.09 & -0.02 & 0.03 & -0.03 & 0.02 & 0.09 \\
\hline Size (2) & -0.04 & . & 0.40 & -0.23 & -0.15 & $\mathbf{0 . 0 7}$ & 0.33 & 0.01 & 0.53 & 0.04 & -0.07 & -0.06 & -0.06 & -0.27 \\
\hline Firm Age (3) & -0.01 & 0.41 & . & -0.24 & -0.16 & -0.02 & 0.12 & -0.03 & 0.13 & 0.03 & -0.05 & -0.10 & -0.10 & -0.08 \\
\hline Return Volatility (4) & 0.03 & -0.20 & -0.24 & . & 0.06 & 0.22 & -0.05 & 0.00 & -0.07 & 0.00 & $\mathbf{0 . 0 7}$ & -0.03 & 0.02 & 0.07 \\
\hline Market-to-Book (5) & -0.03 & -0.12 & -0.16 & -0.02 & . & 0.09 & -0.01 & 0.08 & 0.13 & $\mathbf{0 . 0 7}$ & -0.18 & 0.00 & -0.01 & -0.17 \\
\hline Turnover (6) & -0.03 & 0.14 & 0.03 & 0.20 & 0.16 & . & $\mathbf{0 . 0 7}$ & 0.15 & 0.08 & 0.03 & -0.01 & 0.05 & -0.05 & -0.07 \\
\hline$A D R(7)$ & -0.02 & 0.31 & 0.11 & -0.04 & 0.01 & 0.10 & . & 0.06 & 0.33 & 0.03 & -0.06 & 0.15 & -0.07 & -0.21 \\
\hline Analyst Following (9) & -0.06 & 0.48 & $\mathbf{0 . 0 7}$ & -0.06 & 0.21 & 0.17 & 0.28 & 0.23 & • & 0.09 & -0.22 & 0.11 & -0.07 & -0.56 \\
\hline Forecast Accuracy (10) & -0.02 & 0.04 & 0.02 & 0.01 & 0.09 & 0.05 & 0.03 & 0.03 & 0.12 & . & -0.11 & -0.06 & -0.02 & -0.56 \\
\hline Forecast Diversity (11) & 0.01 & -0.07 & -0.03 & 0.11 & -0.21 & -0.06 & -0.06 & -0.13 & -0.22 & -0.11 & . & 0.03 & 0.00 & 0.62 \\
\hline Big-5 Auditor (12) & -0.02 & -0.07 & -0.10 & -0.05 & -0.02 & 0.02 & 0.15 & 0.07 & 0.10 & -0.05 & 0.03 & • & -0.05 & -0.39 \\
\hline Discretionary Smoothing (13) & $\mathbf{0 . 0 0}$ & -0.06 & -0.10 & 0.01 & -0.03 & -0.07 & -0.07 & -0.07 & -0.07 & -0.02 & 0.00 & -0.05 & & 0.44 \\
\hline Firm-Level Opacity (14) & 0.05 & -0.26 & -0.06 & 0.08 & -0.22 & -0.16 & -0.22 & -0.21 & -0.64 & -0.55 & 0.61 & -0.38 & 0.43 & \\
\hline
\end{tabular}

\begin{tabular}{lrrrr}
\hline VARIABLE & $\mathbf{( 1 5 )}$ & $\mathbf{( 1 6 )}$ & $\mathbf{( 1 7 )}$ & $\mathbf{( 1 8 )}$ \\
\hline Informed Trade (1) & $\mathbf{0 . 0 1}$ & 0.03 & 0.01 & $\mathbf{- 0 . 0 2}$ \\
Size (2) & 0.01 & $\mathbf{- 0 . 0 8}$ & $\mathbf{- 0 . 1 6}$ & 0.13 \\
Firm Age (3) & $\mathbf{0 . 2 5}$ & $\mathbf{0 . 1 0}$ & $\mathbf{0 . 0 7}$ & -0.22 \\
Return Volatility (4) & $\mathbf{- 0 . 0 7}$ & -0.04 & $\mathbf{- 0 . 0 5}$ & $\mathbf{0 . 0 8}$ \\
Market-to-Book (5) & $\mathbf{- 0 . 0 5}$ & 0.01 & $\mathbf{0 . 0 4}$ & $\mathbf{- 0 . 0 2}$ \\
Turnover (6) & $\mathbf{0 . 0 4}$ & $\mathbf{0 . 0 2}$ & $\mathbf{0 . 0 2}$ & $\mathbf{0 . 0 3}$ \\
ADR (7) & $\mathbf{- 0 . 0 9}$ & -0.03 & $\mathbf{- 0 . 0 5}$ & $\mathbf{0 . 0 7}$ \\
Institutional Holdings (8) & $\mathbf{- 0 . 0 5}$ & $-\mathbf{0 . 1 5}$ & $\mathbf{0 . 0 1}$ & $\mathbf{0 . 0 1}$ \\
Firm-Level Opacity (14) & $\mathbf{0 . 0 1}$ & 0.01 & $\mathbf{- 0 . 0 7}$ & 0.01 \\
Media Penetration (15) & $\mathbf{0 . 0 9}$ & $\mathbf{0 . 3 7}$ & $\mathbf{- 0 . 5 4}$ \\
Disclosure (16) & $\mathbf{0 . 0 2}$ & $\cdot$ & $\mathbf{0 . 4 9}$ & $\mathbf{- 0 . 7 3}$ \\
Governance (17) & $\mathbf{0 . 2 5}$ & $\mathbf{0 . 5 2}$ &. & $\mathbf{- 0 . 7 4}$ \\
Country-Level Opacity (18) & $\mathbf{- 0 . 6 1}$ & $\mathbf{- 0 . 7 0}$ & $\mathbf{- 0 . 7 4}$ &. \\
\hline
\end{tabular}

This table reports Pearson correlation coefficients (above the diagonal) and Spearman correlation coefficients (below the diagonal) for variables used in the primary analyses. Correlations that are statistically significant at the $5 \%$ level (or higher) are presented in bold. 


\section{Table 4 - Informed Trading by Institutions and Firm-Level Opacity}

\begin{tabular}{|c|c|c|c|c|c|c|c|c|}
\hline VARIABLES & Prediction & $\begin{array}{l}\text { (1) } \\
\text { IT }\end{array}$ & $\begin{array}{l}\text { (2) } \\
\text { IT }\end{array}$ & $\begin{array}{l}\text { (3) } \\
\text { IT }\end{array}$ & $\begin{array}{l}\text { (4) } \\
\text { IT }\end{array}$ & $\begin{array}{l}\text { (5) } \\
\text { IT }\end{array}$ & $\begin{array}{l}\text { (6) } \\
\text { IT }\end{array}$ & $\begin{array}{l}\text { (7) } \\
\text { IT }\end{array}$ \\
\hline Size & $(-)$ & $\begin{array}{c}-0.080^{* * *} \\
(0.029)\end{array}$ & $\begin{array}{c}-0.226^{* * *} \\
(0.020)\end{array}$ & $\begin{array}{c}-0.171^{* * *} \\
(0.019)\end{array}$ & $\begin{array}{c}-0.174 * * * \\
(0.019)\end{array}$ & $\begin{array}{c}-0.231^{* * *} \\
(0.023)\end{array}$ & $\begin{array}{c}-0.101^{* * *} \\
(0.030)\end{array}$ & $\begin{array}{c}-0.167 * * * \\
(0.021)\end{array}$ \\
\hline Firm Age & $(-)$ & $\begin{array}{c}0.348 \\
(0.279)\end{array}$ & $\begin{array}{c}0.568 * * \\
(0.282)\end{array}$ & $\begin{array}{c}0.055 \\
(0.228)\end{array}$ & $\begin{array}{c}0.080 \\
(0.227)\end{array}$ & $\begin{array}{c}0.797^{* *} \\
(0.347)\end{array}$ & $\begin{array}{c}0.595^{* *} \\
(0.288)\end{array}$ & $\begin{array}{l}0.495^{*} \\
(0.280)\end{array}$ \\
\hline Return Volatility & (?) & $\begin{array}{c}2.026^{* * * *} \\
(0.284)\end{array}$ & $\begin{array}{c}2.170^{* * *} \\
(0.284)\end{array}$ & $\begin{array}{c}1.701^{* * *} \\
(0.272)\end{array}$ & $\begin{array}{c}1.704 * * * \\
(0.271)\end{array}$ & $\begin{array}{c}2.952 * * * \\
(0.341)\end{array}$ & $\begin{array}{c}2.305^{* * *} \\
(0.287)\end{array}$ & $\begin{array}{c}2.124^{* * *} \\
(0.283)\end{array}$ \\
\hline Market-to-Book & (?) & $\begin{array}{c}-0.049 * * * \\
(0.015)\end{array}$ & $\begin{array}{c}-0.079 * * * \\
(0.014)\end{array}$ & $\begin{array}{c}-0.064^{* * *} \\
(0.011)\end{array}$ & $\begin{array}{c}-0.069 * * * \\
(0.011)\end{array}$ & $\begin{array}{c}-0.095^{* * *} \\
(0.016)\end{array}$ & $\begin{array}{c}-0.055^{* * *} \\
(0.015)\end{array}$ & $\begin{array}{c}-0.058^{* * *} \\
(0.014)\end{array}$ \\
\hline Turnover & (?) & $\begin{array}{c}-0.068^{* *} \\
(0.028)\end{array}$ & $\begin{array}{c}-0.099 * * * \\
(0.028)\end{array}$ & $\begin{array}{c}-0.046^{*} \\
(0.024)\end{array}$ & $\begin{array}{c}-0.045^{*} \\
(0.024)\end{array}$ & $\begin{array}{c}-0.116^{* * *} \\
(0.031)\end{array}$ & $\begin{array}{c}-0.064^{* *} \\
(0.028)\end{array}$ & $\begin{array}{c}-0.088^{* * *} \\
(0.028)\end{array}$ \\
\hline$A D R$ & $(-)$ & $\begin{array}{c}0.121 \\
(0.075)\end{array}$ & $\begin{array}{l}-0.022 \\
(0.076)\end{array}$ & $\begin{array}{c}0.040 \\
(0.066)\end{array}$ & $\begin{array}{c}0.038 \\
(0.066)\end{array}$ & $\begin{array}{c}0.004 \\
(0.089)\end{array}$ & $\begin{array}{l}0.138^{*} \\
(0.077)\end{array}$ & $\begin{array}{c}0.039 \\
(0.076)\end{array}$ \\
\hline Institutional Holdings & (?) & $\begin{array}{c}-1.056^{* * *} \\
(0.119)\end{array}$ & $\begin{array}{c}-1.214^{* * *} \\
(0.129)\end{array}$ & $\begin{array}{c}-0.898 * * * \\
(0.108)\end{array}$ & $\begin{array}{c}-0.904 * * * \\
(0.108)\end{array}$ & $\begin{array}{c}-1.148^{* * *} \\
(0.146)\end{array}$ & $\begin{array}{c}-1.010^{* * *} \\
(0.120)\end{array}$ & $\begin{array}{c}-1.115^{* * * *} \\
(0.124)\end{array}$ \\
\hline Analyst Following & $(-)$ & $\begin{array}{c}-0.065^{* * *} \\
(0.007)\end{array}$ & & & & & $\begin{array}{c}-0.057 * * * \\
(0.007)\end{array}$ & \\
\hline Forecast Accuracy & $(-)$ & & $\begin{array}{c}-0.281 * * * \\
(0.099)\end{array}$ & & & & $\begin{array}{c}-0.229 * * \\
(0.101)\end{array}$ & \\
\hline Forecast Diversity & $(+)$ & & & $\begin{array}{c}0.215^{* *} \\
(0.099)\end{array}$ & & & $\begin{array}{l}-0.042 \\
(0.104)\end{array}$ & \\
\hline Big-5 Auditor & $(-)$ & & & & $\begin{array}{l}-0.108^{*} \\
(0.060)\end{array}$ & & $\begin{array}{c}-0.156^{* *} \\
(0.070)\end{array}$ & \\
\hline Discretionary Smoothing & $(+)$ & & & & & $\begin{array}{c}0.310^{* *} \\
(0.130)\end{array}$ & $\begin{array}{l}0.208^{*} \\
(0.120)\end{array}$ & \\
\hline Firm-Level Opacity & $(+)$ & & & & & & & $\begin{array}{c}1.839 * * * \\
(0.207)\end{array}$ \\
\hline Fixed Effects & & C,I,Y & C,I,Y & C,I,Y & C,I,Y & C,I,Y & C,I,Y & C,I,Y \\
\hline Observations & & 43,290 & 43,290 & 33,538 & 33,538 & 32,605 & 41,301 & 43,290 \\
\hline Adjusted R-squared & & 0.028 & 0.025 & 0.025 & 0.024 & 0.027 & 0.029 & 0.027 \\
\hline
\end{tabular}

This table presents results of OLS estimation of the Informed Trading by Institutions and Firm-Level Opacity analysis using firm-level annual observations. In all specifications, Informed Trade (abbreviated IT) is the dependent variable. All variables are calculated as described in Appendix B. Robust standard errors clustered at the firm level are in parentheses. Country (C), industry (I) and year (Y) fixed effects are included in the models as indicated, but I do not report the coefficients. All continuous non-logarithmic variables are winsorized at the $2.5 \%$ level unless otherwise indicated. For the regression analyses, statistical significance is based on two-sided t-tests and indicated as follows: ${ }^{* * *}$ p-value $<0.01$, ${ }^{* *}$ p-value $<0.05$, * p-value $<0.1$. 
Table 5 - Informed Trading by Institutions and Country-Level Opacity

\begin{tabular}{|c|c|c|c|c|c|}
\hline VARIABLES & Prediction & $\begin{array}{l}(1) \\
\text { IT }\end{array}$ & $\begin{array}{l}(2) \\
I T\end{array}$ & $\begin{array}{l}\text { (3) } \\
\text { IT }\end{array}$ & $\begin{array}{l}(4) \\
I T \\
\end{array}$ \\
\hline Size & $(-)$ & $\begin{array}{c}-0.229 * * * \\
(0.054)\end{array}$ & $\begin{array}{c}-0.218^{* * *} \\
(0.052)\end{array}$ & $\begin{array}{c}-0.237 * * * \\
(0.054)\end{array}$ & $\begin{array}{c}-0.222 * * * \\
(0.051)\end{array}$ \\
\hline Firm Age & $(-)$ & $\begin{array}{c}0.736 \\
(0.513)\end{array}$ & $\begin{array}{c}0.795 \\
(0.518)\end{array}$ & $\begin{array}{l}0.927^{*} \\
(0.540)\end{array}$ & $\begin{array}{c}0.794 \\
(0.506)\end{array}$ \\
\hline Return Volatility & (?) & $\begin{array}{c}1.508^{* * * *} \\
(0.319)\end{array}$ & $\begin{array}{c}1.453^{* * *} \\
(0.331)\end{array}$ & $\begin{array}{c}1.427^{* * *} \\
(0.335)\end{array}$ & $\begin{array}{c}1.409 * * * \\
(0.325)\end{array}$ \\
\hline Market-to-Book & (?) & $\begin{array}{c}-0.066^{* * *} \\
(0.022)\end{array}$ & $\begin{array}{c}-0.057^{* *} \\
(0.023)\end{array}$ & $\begin{array}{c}-0.059 * * \\
(0.024)\end{array}$ & $\begin{array}{c}-0.065^{* * *} \\
(0.022)\end{array}$ \\
\hline Turnover & (?) & $\begin{array}{c}-0.100 * * * \\
(0.031)\end{array}$ & $\begin{array}{c}-0.106 * * * \\
(0.031)\end{array}$ & $\begin{array}{l}-0.060 \\
(0.041)\end{array}$ & $\begin{array}{c}-0.090^{* *} \\
(0.036)\end{array}$ \\
\hline$A D R$ & $(-)$ & $\begin{array}{c}0.047 \\
(0.119)\end{array}$ & $\begin{array}{c}0.072 \\
(0.112)\end{array}$ & $\begin{array}{c}0.062 \\
(0.117)\end{array}$ & $\begin{array}{c}0.062 \\
(0.106)\end{array}$ \\
\hline Institutional Holdings & (?) & $\begin{array}{c}-0.820^{* *} \\
(0.337)\end{array}$ & $\begin{array}{c}-0.816^{* * *} \\
(0.288)\end{array}$ & $\begin{array}{c}-0.825^{* * * *} \\
(0.283)\end{array}$ & $\begin{array}{c}-0.824 * * * \\
(0.275)\end{array}$ \\
\hline Firm-Level Opacity & $(+)$ & $\begin{array}{c}1.465 * * * \\
(0.190)\end{array}$ & $\begin{array}{c}1.462 * * * \\
(0.230)\end{array}$ & $\begin{array}{c}1.461^{* * *} \\
(0.229)\end{array}$ & $\begin{array}{c}1.397^{* * *} \\
(0.226)\end{array}$ \\
\hline Media Penetration & $(-)$ & $\begin{array}{c}-0.078^{* * *} \\
(0.012)\end{array}$ & & & \\
\hline Disclosure & $(-)$ & & $\begin{array}{c}-3.706^{* * *} \\
(0.558)\end{array}$ & & \\
\hline Governance & $(-)$ & & & $\begin{array}{c}-0.048^{* * *} \\
(0.008)\end{array}$ & \\
\hline Country-Level Opacity & $(+)$ & & & & $\begin{array}{c}0.425^{* * *} \\
(0.061)\end{array}$ \\
\hline Random Effects & & $\mathrm{C}, \mathrm{I}, \mathrm{Y}$ & C,I,Y & C,I,Y & C,I,Y \\
\hline Observations & & 39,382 & 41,485 & 40,061 & 43,290 \\
\hline Adjusted R-squared & & 0.052 & 0.049 & 0.048 & 0.052 \\
\hline
\end{tabular}

This table presents results of OLS estimation of the Informed Trading by Institutions and Country-Level Opacity analysis using firm-level annual observations. In all specifications, Informed Trade (abbreviated IT) is the dependent variable. All variables are calculated as described in Appendix B. Robust standard errors clustered at the country level are in parentheses. Country (C), industry (I) and year (Y) random effects are included in the models as indicated, but I do not report the coefficients. All continuous non-logarithmic variables are winsorized at the $2.5 \%$ level unless otherwise indicated. For the regression analyses, statistical significance is based on two-sided t-tests and indicated as follows: ${ }^{* * *} \mathrm{p}$-value $<0.01,{ }^{* *} \mathrm{p}$-value $<0.05,{ }^{*} \mathrm{p}$ value $<0.1$. 
Table 6 - Additional Analyses and Robustness Tests

\begin{tabular}{|c|c|c|c|c|c|c|c|c|}
\hline VARIABLES & Prediction & $\begin{array}{c}\text { (1) } \\
\text { Tobit }\end{array}$ & $\begin{array}{c}\text { (2) } \\
\text { Rank Reg. }\end{array}$ & $\begin{array}{c}\text { (3) } \\
\text { EACAR3 }\end{array}$ & $\begin{array}{c}\text { (4) } \\
\text { Uncensored }\end{array}$ & $\begin{array}{c}\text { (5) } \\
\text { Inc. Spread } \\
\end{array}$ & $\begin{array}{c}\text { (6) } \\
F F E\end{array}$ & $\begin{array}{r}(7) \\
\Delta I T \\
\end{array}$ \\
\hline Size & $(-)$ & $\begin{array}{c}-0.287 * * * \\
(0.036)\end{array}$ & $\begin{array}{c}-0.006 * * * \\
(0.001)\end{array}$ & $\begin{array}{c}-0.344 * * * \\
(0.088)\end{array}$ & $\begin{array}{c}-0.064 * * \\
(0.026)\end{array}$ & $\begin{array}{c}0.024 \\
(0.035)\end{array}$ & $\begin{array}{l}-0.117 \\
(0.082)\end{array}$ & $\begin{array}{c}-0.516^{* * *} \\
(0.140)\end{array}$ \\
\hline Firm Age & $(-)$ & $\begin{array}{c}0.744 \\
(0.462)\end{array}$ & $\begin{array}{c}0.010 \\
(0.013)\end{array}$ & $\begin{array}{c}0.386 \\
(1.012)\end{array}$ & $\begin{array}{c}0.700 * * \\
(0.336)\end{array}$ & $\begin{array}{c}0.356 \\
(0.330)\end{array}$ & & \\
\hline Return Volatility & (?) & $\begin{array}{c}2.636 * * * \\
(0.425)\end{array}$ & $\begin{array}{c}0.047 * * * \\
(0.011)\end{array}$ & $\begin{array}{c}1.420 \\
(1.061)\end{array}$ & $\begin{array}{c}0.437 \\
(0.346)\end{array}$ & $\begin{array}{c}1.730^{* * *} \\
(0.336)\end{array}$ & $\begin{array}{c}0.368 \\
(0.279)\end{array}$ & $\begin{array}{l}-0.539 \\
(0.383)\end{array}$ \\
\hline Market-to-Book & (?) & $\begin{array}{c}-0.068 * * * \\
(0.024)\end{array}$ & $\begin{array}{l}-0.001 \\
(0.001)\end{array}$ & $\begin{array}{c}0.008 \\
(0.051)\end{array}$ & $\begin{array}{l}-0.003 \\
(0.018)\end{array}$ & $\begin{array}{l}-0.022 \\
(0.018)\end{array}$ & $\begin{array}{c}-0.047^{* *} \\
(0.019)\end{array}$ & $\begin{array}{l}-0.041 \\
(0.025)\end{array}$ \\
\hline Turnover & (?) & $\begin{array}{c}-0.114 * * \\
(0.047)\end{array}$ & $\begin{array}{l}-0.002 \\
(0.001)\end{array}$ & $\begin{array}{l}-0.109 \\
(0.087)\end{array}$ & $\begin{array}{c}0.003 \\
(0.034)\end{array}$ & $\begin{array}{c}0.037 \\
(0.037)\end{array}$ & $\begin{array}{c}-0.069 * \\
(0.039)\end{array}$ & $\begin{array}{l}-0.017 \\
(0.049)\end{array}$ \\
\hline$A D R$ & $(-)$ & $\begin{array}{c}0.080 \\
(0.138)\end{array}$ & $\begin{array}{c}0.004 \\
(0.004)\end{array}$ & $\begin{array}{l}0.434 * \\
(0.261)\end{array}$ & $\begin{array}{c}0.046 \\
(0.093)\end{array}$ & $\begin{array}{c}0.079 \\
(0.092)\end{array}$ & $\begin{array}{c}0.103 \\
(0.144)\end{array}$ & $\begin{array}{c}0.282 * * \\
(0.123)\end{array}$ \\
\hline Institutional Holdings & (?) & $\begin{array}{c}-1.443^{* * *} \\
(0.234)\end{array}$ & $\begin{array}{c}-0.019 * * \\
(0.007)\end{array}$ & $\begin{array}{c}-0.974 * * \\
(0.447)\end{array}$ & $\begin{array}{c}-0.316^{* *} \\
(0.137)\end{array}$ & $\begin{array}{c}-1.022^{* * *} \\
(0.136)\end{array}$ & $\begin{array}{c}-0.482 * * \\
(0.198)\end{array}$ & $\begin{array}{c}0.061 \\
(0.152)\end{array}$ \\
\hline Spread & $(+)$ & & & & & $\begin{array}{c}0.612^{* * *} \\
(0.069)\end{array}$ & & \\
\hline Firm-Level Opacity & $(+)$ & $\begin{array}{c}2.950 * * * \\
(0.336)\end{array}$ & $\begin{array}{c}0.055 * * * \\
(0.009)\end{array}$ & $\begin{array}{c}2.306 * * * \\
(0.786)\end{array}$ & $\begin{array}{c}1.027 * * * \\
(0.258)\end{array}$ & $\begin{array}{c}1.667 * * * \\
(0.250)\end{array}$ & $\begin{array}{c}0.963 * * * \\
(0.228)\end{array}$ & $\begin{array}{c}0.609 * * \\
(0.250)\end{array}$ \\
\hline Fixed Effects & & C,I,Y & C,I,Y & C,I,Y & C,I,Y & C,I,Y & $F, Y$ & C,I,Y \\
\hline Observations & & 43,290 & 43,290 & 6,335 & 43,290 & 28,968 & 43,290 & 33,517 \\
\hline Adjusted R-squared & & & 0.006 & 0.048 & 0.002 & 0.033 & 0.163 & 0.005 \\
\hline Pseudo R-squared & & 0.004 & & & & & & \\
\hline
\end{tabular}

This table presents results of the Additional Analyses and Robustness Tests using firm-level annual observations. The modifications for each test are indicated in the column heading. All variables are calculated as described in Appendix B. Robust standard errors clustered at the firm level are in parentheses. Country (C), industry (I), firm (F) and year (Y) fixed effects are included in the models as indicated, but I do not report the coefficients. All continuous non-logarithmic variables are winsorized at the $2.5 \%$ level unless otherwise indicated. For the regression analyses, statistical significance is based on two-sided t-tests and indicated as follows: ${ }^{* * *} \mathrm{p}$-value $<0.01,{ }^{* *} \mathrm{p}$-value $<0.05$, * $\mathrm{p}$-value $<0.1$. 
Table 7 - Firm- and Country-Level Opacity Interactions

\begin{tabular}{|c|c|c|c|c|c|}
\hline VARIABLES & Prediction & $\begin{array}{c}\text { (1) } \\
\text { C-L Opacity = } 0\end{array}$ & $\begin{array}{c}(2) \\
\text { C-L Opacity = } 1\end{array}$ & $\begin{array}{c}\text { (3) } \\
\text { C-L Opacity = } 2\end{array}$ & $\begin{array}{c}(4) \\
\text { C-L Opacity }=3\end{array}$ \\
\hline Size & $(-)$ & $\begin{array}{c}-0.463^{* * *} \\
(0.039)\end{array}$ & $\begin{array}{c}-0.343 * * * \\
(0.047)\end{array}$ & $\begin{array}{c}-0.112^{* *} \\
(0.052)\end{array}$ & $\begin{array}{c}-0.198 * * * \\
(0.060)\end{array}$ \\
\hline Firm Age & $(-)$ & $\begin{array}{c}-0.046^{* *} \\
(0.018)\end{array}$ & $\begin{array}{l}-0.026 \\
(0.024)\end{array}$ & $\begin{array}{l}-0.042 \\
(0.026)\end{array}$ & $\begin{array}{l}0.114^{* *} \\
(0.051)\end{array}$ \\
\hline Return Volatility & (?) & $\begin{array}{c}0.428 \\
(0.357)\end{array}$ & $\begin{array}{c}0.995 \\
(0.699)\end{array}$ & $\begin{array}{c}0.494 \\
(0.771)\end{array}$ & $\begin{array}{l}1.992 * * \\
(0.783)\end{array}$ \\
\hline Market-to-Book & (?) & $\begin{array}{c}2.493^{* * * *} \\
(0.530)\end{array}$ & $\begin{array}{c}1.774^{* * *} \\
(0.468)\end{array}$ & $\begin{array}{l}1.477 * * \\
(0.658)\end{array}$ & $\begin{array}{c}0.350 \\
(0.626)\end{array}$ \\
\hline Turnover & (?) & $\begin{array}{l}-0.010 \\
(0.059)\end{array}$ & $\begin{array}{l}-0.027 \\
(0.057)\end{array}$ & $\begin{array}{l}-0.050 \\
(0.040)\end{array}$ & $\begin{array}{l}-0.071 \\
(0.062)\end{array}$ \\
\hline$A D R$ & $(-)$ & $\begin{array}{c}0.216 \\
(0.139)\end{array}$ & $\begin{array}{c}0.075 \\
(0.145)\end{array}$ & $\begin{array}{c}0.128 \\
(0.138)\end{array}$ & $\begin{array}{c}0.218 \\
(0.190)\end{array}$ \\
\hline Institutional Holdings & (?) & $\begin{array}{c}-2.013^{* * *} \\
(0.311)\end{array}$ & $\begin{array}{c}-1.783^{* * *} \\
(0.395)\end{array}$ & $\begin{array}{c}-1.526 * * * \\
(0.462)\end{array}$ & $\begin{array}{c}-0.595^{* * * *} \\
(0.134)\end{array}$ \\
\hline Firm-Level Opacity & $(+)$ & $\begin{array}{c}0.498 \\
(0.409)\end{array}$ & $\begin{array}{l}0.722 * \\
(0.387)\end{array}$ & $\begin{array}{c}1.428^{* * *} \\
(0.370)\end{array}$ & $\begin{array}{c}2.095^{* * *} \\
(0.519)\end{array}$ \\
\hline Opacity Difference (4 - 1) (P-Value) & & & & & $1.597(0.02)$ \\
\hline Fixed Effects & & C,I,Y & C,I,Y & C,I,Y & C,I,Y \\
\hline Observations & & 16,560 & 10,429 & 7,423 & 8,798 \\
\hline Adjusted R-squared & & 0.046 & 0.038 & 0.021 & 0.026 \\
\hline
\end{tabular}

Table 7 presents results of OLS estimation of the Firm- and Country-Level Opacity Interactions analysis using firm-level annual observations. Results are presented for each partition of the aggregate Country-Level Opacity variable. All variables are calculated as described in Appendix B. Robust standard errors clustered at the firm level are in parentheses. Country (C), industry (I) and year (Y) fixed effects are included in the models as indicated, but I do not report the coefficients. All continuous non-logarithmic variables are winsorized at the $2.5 \%$ level unless otherwise indicated. Statistical significance, in the regressions, is based on two-sided t-tests and indicated as follows: *** p-value $<0.01,{ }^{* *}$ p-value $<0.05$, * p-value $<0.1$. Assessments of significance across subgroups are based on the p-value (one-sided) associated with the firm-clustered robust standard errors of the coefficient on the interaction of Firm-Level Opacity and the partitioning variable in a fully-interacted specification. 
Table 8 - Informed Trading and Opacity by Institutional Type

Panel A: Foreign vs. Local

Table 8 - Informed Trading and Opacity by Institutional Type

\begin{tabular}{|c|c|c|c|c|c|c|c|}
\hline VARIABLES & Prediction & $\begin{array}{c}(1) \\
\text { Foreign } \\
\end{array}$ & $\begin{array}{c}(2) \\
\text { Local } \\
\end{array}$ & $\begin{array}{c}\text { (3) } \\
\text { Foreign } \\
\text { Low C-L Opacity } \\
\end{array}$ & $\begin{array}{c}\text { (4) } \\
\text { Foreign } \\
\text { High C-L Opacity }\end{array}$ & $\begin{array}{c}\text { (5) } \\
\text { Local } \\
\text { Low C-L Opacity } \\
\end{array}$ & $\begin{array}{c}\text { (6) } \\
\text { Local } \\
\text { High C-L Opacity }\end{array}$ \\
\hline Size & $(-)$ & $\begin{array}{c}-0.449 * * * \\
(0.016)\end{array}$ & $\begin{array}{c}-0.771^{* * *} \\
(0.034)\end{array}$ & $\begin{array}{c}-0.444 * * * \\
(0.026)\end{array}$ & $\begin{array}{c}-0.385^{* * *} \\
(0.030)\end{array}$ & $\begin{array}{c}-0.509 * * * \\
(0.038)\end{array}$ & $\begin{array}{c}-0.712^{* * *} \\
(0.078)\end{array}$ \\
\hline Firm Age & $(-)$ & $\begin{array}{c}-0.085^{* * *} \\
(0.009)\end{array}$ & $\begin{array}{c}-0.201 * * * \\
(0.018)\end{array}$ & $\begin{array}{c}-0.081^{* * *} \\
(0.014)\end{array}$ & $\begin{array}{c}-0.102^{* * *} \\
(0.021)\end{array}$ & $\begin{array}{c}-0.109^{* * *} \\
(0.020)\end{array}$ & $\begin{array}{c}-0.209^{* * *} \\
(0.049)\end{array}$ \\
\hline Return Volatility & (?) & $\begin{array}{c}-0.293^{*} \\
(0.169)\end{array}$ & $\begin{array}{c}0.079 \\
(0.353)\end{array}$ & $\begin{array}{l}-0.324 \\
(0.245)\end{array}$ & $\begin{array}{c}-0.679 * \\
(0.374)\end{array}$ & $\begin{array}{l}-0.137 \\
(0.341)\end{array}$ & $\begin{array}{c}-2.302^{* *} \\
(1.063)\end{array}$ \\
\hline Market-to-Book & (?) & $\begin{array}{c}-0.768 * * * \\
(0.178)\end{array}$ & $\begin{array}{l}-0.714^{*} \\
(0.368)\end{array}$ & $\begin{array}{c}-0.836 * * * \\
(0.289)\end{array}$ & $\begin{array}{l}-0.334 \\
(0.403)\end{array}$ & $\begin{array}{c}0.577 \\
(0.401)\end{array}$ & $\begin{array}{l}-1.182 \\
(0.958)\end{array}$ \\
\hline Turnover & $(+)$ & $\begin{array}{c}0.069 * * * \\
(0.020)\end{array}$ & $\begin{array}{c}0.081^{*} \\
(0.048)\end{array}$ & $\begin{array}{l}0.074 * * \\
(0.029)\end{array}$ & $\begin{array}{c}0.088 \\
(0.056)\end{array}$ & $\begin{array}{l}-0.053 \\
(0.041)\end{array}$ & $\begin{array}{c}0.057 \\
(0.142)\end{array}$ \\
\hline$A D R$ & $(-)$ & $\begin{array}{l}-0.079 * \\
(0.043)\end{array}$ & $\begin{array}{c}0.076 \\
(0.124)\end{array}$ & $\begin{array}{l}-0.085 \\
(0.060)\end{array}$ & $\begin{array}{c}-0.273^{* * * *} \\
(0.090)\end{array}$ & $\begin{array}{l}-0.041 \\
(0.079)\end{array}$ & $\begin{array}{l}0.729 * * \\
(0.311)\end{array}$ \\
\hline Institutional Holdings & (?) & $\begin{array}{c}0.637^{* * *} \\
(0.141)\end{array}$ & $\begin{array}{c}1.918^{* * *} \\
(0.419)\end{array}$ & $\begin{array}{c}0.213 \\
(0.330)\end{array}$ & $\begin{array}{c}1.012^{* * *} \\
(0.185)\end{array}$ & $\begin{array}{c}0.452 \\
(0.359)\end{array}$ & $\begin{array}{c}3.581^{* * *} \\
(0.594)\end{array}$ \\
\hline Firm-Level Opacity & $(+)$ & $\begin{array}{c}1.181^{* * * *} \\
(0.150)\end{array}$ & $\begin{array}{c}1.663^{* * *} \\
(0.325)\end{array}$ & $\begin{array}{c}0.828 * * * \\
(0.226)\end{array}$ & $\begin{array}{c}1.367^{* * * *} \\
(0.336)\end{array}$ & $\begin{array}{c}1.263^{* * * *} \\
(0.324)\end{array}$ & $\begin{array}{c}2.692^{* * *} \\
(0.749)\end{array}$ \\
\hline Opacity Difference (P-Value) & & \multicolumn{2}{|c|}{$\begin{array}{c}0.482(0.08) \\
(2)-(1)\end{array}$} & \multicolumn{2}{|c|}{$\begin{array}{c}0.539(0.09) \\
(4)-(3)\end{array}$} & \multicolumn{2}{|c|}{$\begin{array}{c}1.429(0.04) \\
(6)-(5)\end{array}$} \\
\hline Opacity Difference (P-Value) & & & & \multicolumn{2}{|c|}{$\begin{array}{c}0.435(0.13) \\
(5)-(3)\end{array}$} & \multicolumn{2}{|c|}{$\begin{array}{c}1.305(0.04) \\
(6)-(4)\end{array}$} \\
\hline Fixed Effects & & C,I,Y & C,I,Y & C,I,Y & C,I,Y & C,I,Y & C,I,Y \\
\hline Observations & & 27,739 & 33,356 & 11,590 & 5,337 & 14,038 & 6,161 \\
\hline Adjusted R-squared & & 0.087 & 0.064 & 0.078 & 0.100 & 0.053 & 0.065 \\
\hline
\end{tabular}


TABLE 8 - (continued)

\begin{tabular}{|c|c|c|c|c|c|c|c|}
\hline VARIABLES & Prediction & $\begin{array}{c}(1) \\
\text { Dedicated } \\
\end{array}$ & $\begin{array}{c}(2) \\
\text { Transient } \\
\end{array}$ & $\begin{array}{c}\text { (3) } \\
\text { Dedicated } \\
\text { Low C-L Opacity }\end{array}$ & $\begin{array}{c}\text { (4) } \\
\text { Dedicated } \\
\text { High C-L Opacity }\end{array}$ & $\begin{array}{c}\text { (5) } \\
\text { Transient } \\
\text { Low C-L Opacity }\end{array}$ & $\begin{array}{c}\text { (6) } \\
\text { Transient } \\
\text { High C-L Opacity }\end{array}$ \\
\hline Size & $(-)$ & $\begin{array}{c}-0.506^{* * *} \\
(0.027)\end{array}$ & $\begin{array}{c}-1.374 * * * \\
(0.060)\end{array}$ & $\begin{array}{c}-0.460 \text { *** } \\
(0.040)\end{array}$ & $\begin{array}{c}-0.425^{* * *} \\
(0.053)\end{array}$ & $\begin{array}{c}-1.385^{* * *} \\
(0.099)\end{array}$ & $\begin{array}{c}-1.264^{* * *} \\
(0.116)\end{array}$ \\
\hline Firm Age & $(-)$ & $\begin{array}{c}-0.095^{* * *} \\
(0.014)\end{array}$ & $\begin{array}{c}-0.295^{* * *} \\
(0.033)\end{array}$ & $\begin{array}{l}-0.029 \\
(0.022)\end{array}$ & $\begin{array}{c}-0.147^{* * *} \\
(0.030)\end{array}$ & $\begin{array}{c}-0.234^{* * *} \\
(0.056)\end{array}$ & $\begin{array}{c}-0.345^{* * *} \\
(0.080)\end{array}$ \\
\hline Return Volatility & (?) & $\begin{array}{c}-0.555^{* *} \\
(0.262)\end{array}$ & $\begin{array}{l}-0.150 \\
(0.632)\end{array}$ & $\begin{array}{l}-0.304 \\
(0.354)\end{array}$ & $\begin{array}{c}0.122 \\
(0.655)\end{array}$ & $\begin{array}{c}1.052 \\
(1.031)\end{array}$ & $\begin{array}{l}-1.379 \\
(1.312)\end{array}$ \\
\hline Market-to-Book & (?) & $\begin{array}{c}-0.717^{* *} \\
(0.302)\end{array}$ & $\begin{array}{c}-2.192 * * * \\
(0.706)\end{array}$ & $\begin{array}{c}-0.885^{* *} \\
(0.431)\end{array}$ & $\begin{array}{l}-0.816 \\
(0.631)\end{array}$ & $\begin{array}{l}-1.830 \\
(1.241)\end{array}$ & $\begin{array}{c}-2.900^{* *} \\
(1.372)\end{array}$ \\
\hline Turnover & $(+)$ & $\begin{array}{c}0.107^{* * *} \\
(0.040)\end{array}$ & $\begin{array}{c}0.055 \\
(0.071)\end{array}$ & $\begin{array}{l}-0.005 \\
(0.052)\end{array}$ & $\begin{array}{c}0.121 \\
(0.096)\end{array}$ & $\begin{array}{l}-0.083 \\
(0.137)\end{array}$ & $\begin{array}{c}0.066 \\
(0.173)\end{array}$ \\
\hline$A D R$ & $(-)$ & $\begin{array}{l}-0.148 * \\
(0.076)\end{array}$ & $\begin{array}{l}-0.262 * \\
(0.148)\end{array}$ & $\begin{array}{l}-0.011 \\
(0.093)\end{array}$ & $\begin{array}{l}-0.302 * \\
(0.167)\end{array}$ & $\begin{array}{l}-0.323 \\
(0.211)\end{array}$ & $\begin{array}{l}-0.351 \\
(0.365)\end{array}$ \\
\hline Institutional Holdings & (?) & $\begin{array}{c}1.490^{* * *} \\
(0.261)\end{array}$ & $\begin{array}{l}1.159 * * \\
(0.504)\end{array}$ & $\begin{array}{c}1.618 * * * \\
(0.618)\end{array}$ & $\begin{array}{c}1.892^{* * *} \\
(0.362)\end{array}$ & $\begin{array}{l}2.394 * \\
(1.236)\end{array}$ & $\begin{array}{c}1.125 \\
(0.711)\end{array}$ \\
\hline Firm-Level Opacity & $(+)$ & $\begin{array}{c}0.912^{* * *} \\
(0.252)\end{array}$ & $\begin{array}{c}4.254^{* * *} \\
(0.573)\end{array}$ & $\begin{array}{c}0.141 \\
(0.319)\end{array}$ & $\begin{array}{l}1.248 * * \\
(0.532)\end{array}$ & $\begin{array}{c}4.649 * * * \\
(0.904)\end{array}$ & $\begin{array}{c}4.708^{* * *} \\
(1.139)\end{array}$ \\
\hline Opacity Difference (P-Value) & & \multicolumn{2}{|c|}{$\begin{array}{c}3.342(0.00) \\
(2)-(1)\end{array}$} & \multicolumn{2}{|c|}{$\begin{array}{c}1.106(0.03) \\
(4)-(3)\end{array}$} & \multicolumn{2}{|c|}{$\begin{array}{c}0.059(0.43) \\
(6)-(5)\end{array}$} \\
\hline Opacity Difference (P-Value) & & & & \multicolumn{2}{|c|}{$\begin{array}{c}4.507(0.00) \\
(5)-(3)\end{array}$} & \multicolumn{2}{|c|}{$\begin{array}{c}3.460(0.00) \\
(6)-(4)\end{array}$} \\
\hline Fixed Effects & & C,I,Y & C,I,Y & C,I,Y & C,I,Y & C,I,Y & C,I,Y \\
\hline Observations & & 22,880 & 22,243 & 9,835 & 4,348 & 9,015 & 4,531 \\
\hline Adjusted R-squared & & 0.067 & 0.066 & 0.059 & 0.074 & 0.065 & 0.071 \\
\hline
\end{tabular}

Table 8 Panels A and B present results of OLS estimation of the Informed Trading and Opacity by Institutional Type analysis using firm-level annual observations. Panel A presents results for Foreign and Local institutional subgroups. Panel B presents results for Dedicated and Transient institutional subgroups. All variables are calculated as described in Appendix B. Robust standard errors clustered at the firm level are in parentheses. Country (C), industry (I) and year (Y) fixed effects are included in the models as indicated, but I do not report the coefficients. All continuous non-logarithmic variables 
are winsorized at the $2.5 \%$ level unless otherwise indicated. Statistical significance, in the regressions, is based on two-sided t-tests and indicated as follows: *** p-value $<0.01,{ }^{* *}$ p-value $<0.05, *$ p-value $<0.1$. Assessments of significance across subgroups are based on the p-value (one-sided) associated with the firm-clustered robust standard errors of the coefficient on the interaction of Firm-Level Opacity and the partitioning variable in a fully-interacted specification. 
TABLE 9 - Difference-in-Differences Returns Tests

Panel A: Portfolios based on Firm-Level Opacity

\begin{tabular}{|c|c|c|c|}
\hline AHoldings Decile & Opaque & Transparent & \\
\hline D10 (High) & $0.7 \%$ & $-1.0 \%$ & \\
\hline D1 (Low) & $-5.1 \%$ & $0.2 \%$ & \\
\hline High - Low & $5.8 \%$ & $-1.2 \%$ & $7.0 \%$ \\
\hline p-value & $(0.01)$ & $(0.29)$ & $(0.02)$ \\
\hline
\end{tabular}

Panel B: Portfolios based on Country-Level Opacity

\begin{tabular}{|c|c|c|c|}
\hline $\Delta$ Holdings Decile & Opaque & Transparent & \\
\hline D10 (High) & $-0.1 \%$ & $1.6 \%$ & \\
\hline D1 (Low) & $-4.6 \%$ & $1.2 \%$ & \\
\hline High - Low & $4.5 \%$ & $0.4 \%$ & $4.1 \%$ \\
\hline p-value & $(0.01)$ & $(0.40)$ & $(0.04)$ \\
\hline
\end{tabular}

Panel C: Portfolios based on Firm- and Country-Level Opacity

\begin{tabular}{|c|c|c|c|}
\hline$\Delta$ Holdings Decile & Opaque & Transparent & \\
\hline D10 (High) & $0.5 \%$ & $2.8 \%$ & \\
\hline D1 (Low) & $-6.0 \%$ & $1.5 \%$ & \\
\hline $\begin{array}{l}\text { High - Low } \\
\text { p-value }\end{array}$ & $\begin{array}{l}6.5 \% \\
(0.07)\end{array}$ & $\begin{array}{l}1.3 \% \\
(0.37)\end{array}$ & $\begin{array}{l}5.2 \% \\
(0.13)\end{array}$ \\
\hline
\end{tabular}

Table 9 Panels A-E present results for the Difference-in-Differences Returns tests. Panel A presents results for portfolios partitioned based on deciles of changes in institutional holdings and deciles of Firm-Level Opacity. Panel B presents results for portfolios partitioned based on deciles of changes in institutional holdings and Country-Level Opacity, where the 'Opaque' firms are domiciled in countries with Country-Level Opacity scores of 3 and the 'Transparent' firms are domiciled in countries with Country-Level Opacity scores of 0. Panel C presents results for portfolios partitioned based on deciles of changes in institutional holdings and deciles of Firm-Level Opacity, where the 'Opaque' firms are domiciled in countries with Country-Level Opacity scores of 3 and the 'Transparent' firms are domiciled in countries with Country-Level Opacity scores of 0. Panel D presents results for portfolios partitioned based on deciles of changes in institutional holdings and Foreign and Local investors for firms in the highest decile of Firm-Level Opacity. Panel E presents results for portfolios partitioned based on deciles of changes in institutional holdings and Transient and Dedicated investors for firms in the highest decile of Firm-Level Opacity. Statistical significance within opacity deciles is based on the p-value (one-sided) of the time-series average of the difference in the 90-day portfolio returns across change in institutional holdings deciles. Statistical significance across opacity (institution-type) groups is based the on p-value (one-sided) of the time-series average of the difference in the difference of 90-day portfolio returns across the partitioning variable.

Panel D: Portfolios based on Investor Location

\begin{tabular}{|c|c|c|c|}
\hline $\Delta$ Holdings Decile & $\begin{array}{c}\text { Local } \\
\text { Opaque }\end{array}$ & $\begin{array}{c}\text { Foreign } \\
\text { Opaque }\end{array}$ & \\
\hline D10 (High) & $0.1 \%$ & $0.7 \%$ & \\
\hline D1 (Low) & $-6.9 \%$ & $-1.9 \%$ & \\
\hline $\begin{array}{l}\text { High - Low } \\
\text { p-value }\end{array}$ & $\begin{array}{c}7.0 \% \\
(0.02)\end{array}$ & $\begin{array}{l}2.6 \% \\
(0.17)\end{array}$ & $\begin{array}{l}4.4 \% \\
(0.09)\end{array}$ \\
\hline
\end{tabular}

Panel E: Portfolios based on Investment Horizon

\begin{tabular}{|c|c|c|c|}
\hline$\Delta$ Holdings Decile & $\begin{array}{l}\text { Transient } \\
\text { Opaque } \\
\end{array}$ & $\begin{array}{c}\text { Dedicated } \\
\text { Opaque }\end{array}$ & \\
\hline D10 (High) & $1.2 \%$ & $1.0 \%$ & \\
\hline D1 (Low) & $-3.7 \%$ & $0.3 \%$ & \\
\hline High - Low & $4.9 \%$ & $0.7 \%$ & $4.2 \%$ \\
\hline p-value & $(0.02)$ & $(0.37)$ & $(0.08)$ \\
\hline
\end{tabular}




\section{Appendix A. Timeline for variable measurement}

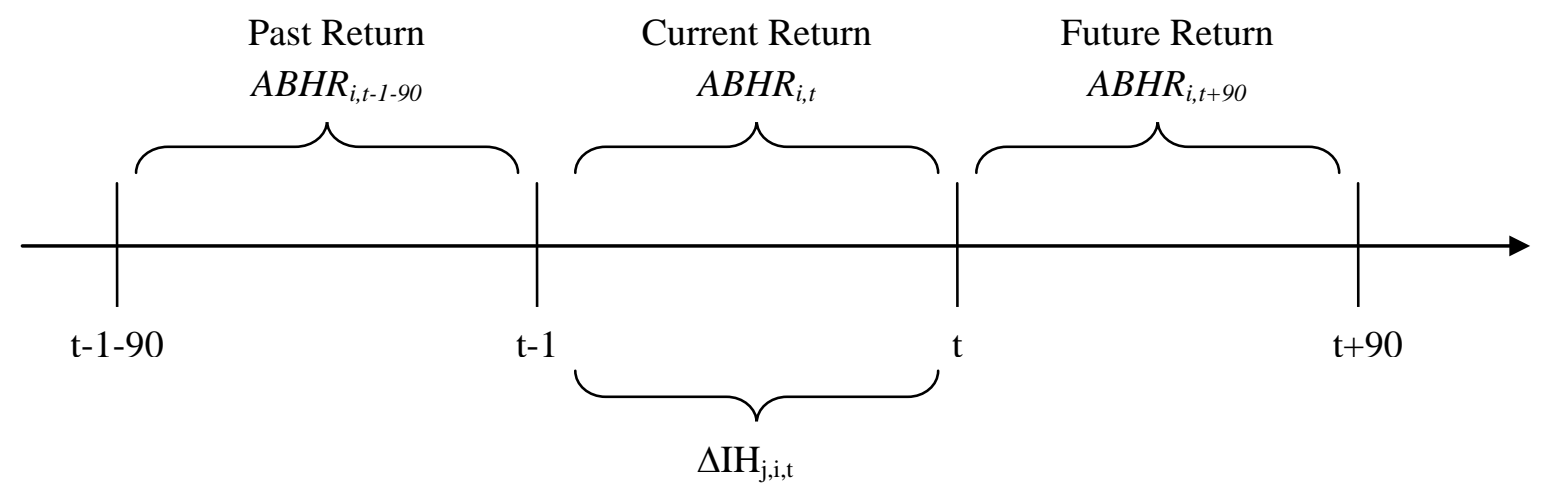




\section{Appendix B. Variable Definitions}

Variable

ABHR

Market Value of Equity

Book-to-Market

E/P Ratio

Lagged Return

$\Delta I H$

Informed Trade

Size

Firm Age

Return Volatility

Market-to-Book

Turnover

$A D R$

Institutional Holdings

Analyst Following

Forecast Accuracy

Forecast Diversity
Definition

the firm's risk-adjusted buy-and-hold return less the buy-and-hold return for the market in the firm's country of domicile, where the risk-adjusted return is the residual value from a regression of the market-adjusted buy-and-hold return on the firm's decile rank of Market Value of Equity, Book-to-Market, E/P Ratio and Lagged Return, as defined below

the natural log of the market value of equity in U.S.D. (millions) (Datastream item MV)

book value of common equity (WorldScope item 03501) divided by market value of common equity (Datastream item MV)

net income before extraordinary items (WorldScope item 01551) divided by market value of common equity (Datastream item MV)

the firm's buy-and-hold return over the previous 12 months (Datastream item RI)

is the change in percent of total shares held by institution $j$ in firm $i$ from time $t-1$ to $t$ multiplied by 1,000 and winsorized at the $5 \%$ level

the beta coefficient from a regression of changes in institutional holdings on future returns calculated as described in Section 4.1, multiplied by 100 for readability

the natural log of total assets in U.S.D. (millions) (WorldScope item 02999)

the age of the firm in months (Datastream item BDATE) divided by 1,000

the annualized standard deviation of daily stock returns (Datastream item RI)

market value of common equity (Datastream item MV) divided by book value of common equity (WorldScope item 03501)

is the total annual volume of shares traded over the firm's fiscal year (Datastream item VO), divided by the total number of shares outstanding at the end of the fiscal year (Datastream item NOSH)

an indicator variable equal to one if the firm trades on a U.S. exchange during the year, and zero otherwise (data are hand-collected from a variety of sources including the Bank of New York, Citibank, JP Morgan and Datastream)

the firm's total shares held by institutions in the TIMF database, divided by the total number of shares outstanding (Datastream item NOSH) at the end of the calendar year

the number of unique analysts making a forecast of the firm's annual earnings, obtained from the $I / B / E / S$ Summary File

the percentile-ranked residual value from a regression of Raw Accuracy on Earnings Surprise and Forecast Bias, where Raw Accuracy is the absolute value of the forecast error multiplied by -1 , scaled by the stock price at the end of the prior fiscal year and where the forecast error is the analysts' mean annual earnings forecast less the actual earnings as reported in the $I / B / E / S$ Summary File

the percentile-ranked residual value from a regression of Raw Diversity on Earnings Surprise and Forecast Bias, where Raw Diversity is the standard deviation of analysts' forecasts of the firm's earnings in the following year, normalized by the mean forecast and then divided by the square root of the number 
Earnings Surprise

Forecast Bias

Big-5 Auditor

Discretionary

Smoothing

Firm-Level Opacity

Media Penetration

Disclosure

Governance

Country-Level Opacity

Spread

Foreign

Local

Dedicated

Transient of analysts following that firm, where all values are taken from the $I / B / E / S$ Summary File

unexpected earnings scaled by stock price at the end of the prior fiscal year (Datastream item P), where unexpected earnings is defined as earnings per share (WorldScope item 05201) less earnings per share from the prior fiscal year

the signed value of the forecast error scaled by stock price at the end of the prior fiscal year, where the forecast error is the $I / B / E / S$ analysts' mean annual earnings forecast less the actual earnings as reported in the $I / B / E / S$ Summary File

an indicator variable equal to one if the firm is audited by a 'Big-5' auditing firm during the fiscal year, and zero otherwise (collected from a variety of sources, including historical point-in-time Datastream data and Compustat Global)

the firm's discretionary earnings smoothing, calculated following Lang et al. (2011)

the average scaled percentile rank of the variables: (1-Analyst Following), (1Forecast Accuracy), (1-Big-5 Auditor), Forecast Diversity and Discretionary Smoothing

is an index constructed from the World Bank's World Development Indicators, in which each country is ranked based on the number of newspapers, internet connections and televisions per capita from 1994 to 2004 and higher scores correspond to better media penetration (the best possible score is 100)

is the disclosure index as reported in La Porta et al. (2006)

the governance index as reported in Bushman et al. (2004)

is a country-level index, ranging from $0-3$, constructed by summing the instances in which a country has a median value of Media Penetration, Disclosure or Governance below the median

the natural log of the median bid-ask spread over the fiscal year, where the bid ask spread is equal to (ASK-BID)/((ASK+BID)/2))

is an institution-level indicator variable equal to one if the institution is located in a different country than the target firm, and zero otherwise

is an institution-level indicator variable equal to one if the institution is located in the same country as the target firm, and zero otherwise

is an institution-level indicator variable equal to one if an institution is in the lowest quintile of portfolio turnover in a particular year, and zero otherwise

is an institution-level indicator variable equal to one if an institution is in the highest quintile of portfolio turnover in a particular year, and zero otherwise 


\section{REFERENCES}

AGGARWAL, R.; I. EREL; M. FERREIRA; and P. MATOS. "Does Governance Travel around the World? Evidence from Institutional Investors.” Journal of Financial Economics 100 (2011): 154181.

ALI, A.; C. DURTSCHI; B. LEV; and M. TROMBLEY. "Changes in Institutional Ownership and Subsequent Earnings Announcement Abnormal Returns.” Journal of Accounting, Auditing \& Finance 19 (2004): 221-48.

BAIK, B.; J. KANG; and J. KIM. "Local Institutional Investors, Information Asymmetries, and Equity Returns.” Journal of Financial Economics 97 (2010): 81-106.

BROWN, S., and A. HILLEGEIST. "How Disclosure Quality Affects the Level of Information Asymmetry.” Review of Accounting Studies 12 (2007): 443-477.

BUSHEE, B. “Do Institutional Investors Prefer Near-Term Earnings over Long-Run Value?” Contemporary Accounting Research 18 (2001): 207-246.

BUSHEE, B., and T. GOODMAN. "Which Institutional Investors Trade Based on Private Information About Earnings and Returns?” Journal of Accounting Research 45 (2007): 289-322.

BUSHEE, B., and C. NOE. "Corporate Disclosure Practices, Institutional Investors, and Stock Return Volatility.” Journal of Accounting Research 38 (2000): 171-202.

BUSHMAN, R.; J. PIOTROSKI; and A. SMITH. "What Determines Corporate Transparency?" Journal of Accounting Research 42 (2004): 207-252.

CAI, F., and L. ZHENG. "Institutional Trading and Stock Returns." Finance Research Letters 1 (2004): 178-189.

CAMPBELL, J.; T. RAMADORAI; and T. VUOLTEENAHO. "Caught on Tape: Institutional Order Flow and Stock Returns.” Unpublished paper, National Bureau of Economic Research, 2005.

CARHART, M. “On Persistence in Mutual Fund Performance.” The Journal of Finance 52 (1997): 57-82.

CHAN, K.; V. COVRIG; and L. NG. "What Determines the Domestic Bias and Foreign Bias? Evidence from Mutual Fund Equity Allocations Worldwide.” The Journal of Finance 60 (2005): 1495-1534.

COLLINS, D.; S. KOTHARI; J. SHANKEN; and R. SLOAN. "Lack of Timeliness and Noise as Explanations for the Low Contemporaneous Return-Earnings Association.” Journal of Accounting and Economics 18 (1994): 289-324.

DASKE, H.; L. HAIL; C. LEUZ and R. VERDI. "Mandatory IFRS Reporting around the World: Early Evidence on the Economic Consequences." Journal of Accounting Research 46 (2008): 10851142.

DEFOND, M., and J. JIAMBALVO. "Factors Related to Auditor-Client Disagreements Over Income-Increasing Accounting Methods.” Contemporary Accounting Research 9 (1993): 415-431. 
DIAMOND, D. “Optimal Release of Information by Firms.” The Journal of Finance 40 (1985): 1071-1094.

DUMAS, B.; K. LEWIS; and E. OSAMBELA. "Differences of Opinion and International Equity Markets.” Unpublished paper, National Bureau of Economic Research, 2011.

DYCK, A.; K. LINS; and L. POMORSKI. "Does Active Management Pay? New International Evidence.” Unpublished paper, University of Toronto (2011).

EASLEY, D.; S. HVIDKJAER; and M. O'HARA. "Is Information Risk a Determinant of Asset Returns?” The Journal of Finance 57 (2002): 2185-2221.

FAMA, E., and K. FRENCH. "Value versus Growth: The International Evidence." The Journal of Finance 53 (1998): 1975-1999.

FERREIRA, M., and P. MATOS. "The Colors of Investors' Money: The Role of Institutional Investors around the World.” Journal of Financial Economics 88 (2008): 499-533.

GOMPERS, P., and A. METRICK. "Institutional Investors and Equity Prices.” The Quarterly Journal of Economics 116 (2001): 229-259.

HAU, H., and H. REY. "Home Bias at the Fund Level.” American Economic Review 98 (2008): 333338.

JIN, C., and S. MYERS. "R ${ }^{2}$ Around the World: New Theory and New Tests." Journal of Financial Economics 79 (2006): 257-292.

KE, B., and K PETRONI. "How Informed are Actively Trading Institutional Investors? Evidence from Their Trading Behavior before a Break in a String of Consecutive Earnings Increases." Journal of Accounting Research 42 (2004): 895-927.

KE, B.; K. PETRONI; and Y. YU. "The Effect of Regulation FD on Transient Institutional Investors' Trading Behavior.” Journal of Accounting Research 46 (2008): 853-883.

KHORANA, A.; H. SERVAES; and P. TUFANO. "Mutual Fund Fees Around the World." The Review of Financial Studies 22 (2009): 1279-1310.

KIM, O., and R. VERRECCHIA. "Pre-Announcement and Event-Period Private Information." Journal of Accounting and Economics 24 (1997): 395-419.

KYLE, A. “Continuous Auction and Insider Trading.” Econometrica 53 (1985): 1315-1335.

LA PORTA, R.; F. LOPEZ-DE-SILANES; and A. SHLEIFER. "What Works in Securities Laws." The Journal of Finance 61 (2006): 1-32.

LA PORTA, R.; F. LOPEZ-DE-SILANES; A. SHLEIFER; and R. W. VISHNY. "Legal Determinants of External Finance.” The Journal of Finance 52 (1997): 1131-50. 
LANG, M.; K. LINS; and M. MAFFETT. "Transparency, Liquidity and Valuation: International Evidence on When Transparency Matters Most.” Journal of Accounting Research, forthcoming, 2011.

LANG, M.; K. LINS; and D. MILLER. “ADRs, Analysts, and Accuracy: Does Cross Listing in the United States Improve a Firm's Information Environment and Increase Market Value?” Journal of Accounting Research 41 (2003): 317-345.

LANG, M.; K. LINS; and D. MILLER. "Concentrated Control, Analyst Following, and Valuation: Do Analysts Matter Most When Investors are Protected Least?” Journal of Accounting Research 42 (2004): 581-623.

LANG, M., and R. LUNDHOLM. "Corporate Disclosure Policy and Analyst Behavior." The Accounting Review 71 (1996): 467-493.

LANG, M., and M. MAFFETT. "Economic effects of Transparency in International Equity Markets: A Review and Suggestions for Future Research.” Foundations and Trends in Accounting 5 (2011a): 175-241.

LANG, M., and M. MAFFETT. “Transparency and Liquidity Uncertainty in Crisis Periods.” Journal of Accounting and Economics 52 (2011b): 101-125.

LEUZ, C.; K. LINS; and F. WARNOCK. “Do Foreigners Invest Less in Poorly Governed Firms?” The Review of Financial Studies 23 (2010): 3245-3285.

LEUZ, C.; D. NANDA; and P. WYSOCKI. "Earnings Management and Investor Protection: An International Comparison.” Journal of Financial Economics 69 (2003): 505-527.

LEUZ, C., and R. VERRECCHIA. “The Economic Consequences of Increased Disclosure.” Journal of Accounting Research 38 (2000): 353-386.

PINCUS, M.; S. RAJGOPAL; and M. VENKATACHALAM. "The Accrual Anomaly: International Evidence.” The Accounting Review 82 (2007): 169-203.

SIAS, R.; L. STARKS; and S. TITMAN. "Changes in Institutional Ownership and Stock Returns: Assessment and Methodology.” Journal of Business 79 (2006): 2869-2910.

TEOH, S., and T. WONG. "Perceived Auditor Quality and the Earnings Response Coefficient.” The Accounting Review 68 (1993): 346-366.

VERRECCHIA, R. "Information Acquisition in a Noisy Rational Expectations Economy." Econometrica 50 (1982): 1415-1430.

YAN, X., and Z. ZHANG. "Institutional Investors and Equity Returns: Are Short-term Institutions Better Informed?” The Review of Financial Studies 22 (2009): 893-924.

YU, G. "Accounting Standards and International Portfolio Holdings: Analysis of Cross-Border Holdings Following Mandatory Adoption of IFRS.” Unpublished paper, Harvard University, 2010. 